\title{
White House Review of Agency Rulemaking: An Empirical Investigation
}

\author{
Steven Croley†
}

Among the many important developments in administrative law over the past two decades-indeed among developments in domestic policymaking generally-efforts by recent presidents to exert greater control over regulatory agencies rank near the very top. As many have observed, ${ }^{\text {' }}$ recent presidential administrations, beginning most significantly with the administration of President Ronald Reagan, have sought to exercise increased influence over agency decisionmaking in both procedural and substantive ways. Procedurally, presidents have required agencies to inform the White House of important pending regulatory actions and, far beyond that, to seek some form of White House approval for those actions. Substantively, recent presidents have required agencies to demonstrate to the White House, in the course of getting approval for their pending regulatory decisions, that major regulatory actions are justified by one form or another of cost-benefit analysis, and that those actions otherwise conform to the president's own regulatory priorities. While this trend toward greater executive control over agencies was originally closely associated with the deregulatory agenda of the President Reagan and President George H.W. Bush administrations, ${ }^{2}$ President Clinton reincarnated

$\dagger$ Professor of Law, University of Michigan Law School. A.B., University of Michigan; J.D., Yale Law School; Ph.D. (Politics), Princeton University. Thanks to Curtis Copeland, Rick Hills, Kevin Karty, Nina Mendelson, Rick Pildes, Susan Rose-Ackerman, Peter Strauss, Tom Sussman, David Vladek, Chuck Weisselberg, and Norman Williams for helpful comments. Thanks also to Kevin Karty for assistance with some of the technical portions of this Article. Thanks finally to participants at the University of California at Berkeley, Boalt Hall, Brown Bag Workshop, the 2003 Midyear section meeting of the Administrative Law \& Regulatory Practice Section of the American Bar Association and the University of Southern California Law School's Law \& Economics Workshop. The University of Michigan Law School Cook Research Fund provided support for this research.

1 See, for example, Elena Kagan, Presidential Administration, 114 Harv L Rev 2245, 2246-47 (2001); Richard H. Pildes and Cass R. Sunstein, Reinventing the Regulatory State, $62 \mathrm{U}$ Chi L Rev 1, 3 (1995); Lawrence Lessig and Cass R. Sunstein, The President and the Administration, 94 Colum L Rev 1, 6-7 (1994); Peter L. Strauss and Cass R. Sunstein, The Role of the President and $O M B$ in Informal Rulemaking, 38 Admin L Rev 181,185 (1986).

2 See, for example, Peter M. Shane, Political Accountability in a System of Checks and Balances: The Case of Presidential Review of Rulemaking, 48 Ark L Rev 161, 162 (1995) (noting "the Reagan and [George H.W.] Bush Administrations' redesign of executive branch mechanisms for the centralized review of regulatory policy"); Christopher C. DeMuth and Douglas H. Ginsburg, White House Review of Agency Rulemaking, 99 Harv L Rev 1075, 1075-76 (1986) (outlining President Reagan's program to assert control over agency rulemaking); Alan B. Mor- 
earlier Republican efforts to effect greater control over agencies, and White House oversight eventually was seen as a potential friend of regulatory government.

But while greater presidential control over agencies came to be embraced by both political parties as each alternately occupied the White House, scholars and commentators remain divided over the desirability of greater White House influence on regulatory decisionmaking. ${ }^{3}$ On the one side, defenders of what can be thought of as "activist" White House oversight see greater presidential control as a welcome and perhaps even constitutionally necessary development. On the other side, critics worry that greater presidential control makes for poor regulatory policy, threatens congressional will, or jeopardizes careful balances between law and politics that characterize the administrative state. This general debate over the "strong president" is really three debates in one-a descriptive debate, a normative debate, and a legal-constitutional argument. The descriptive debate considers just how far increased presidential control has really come and, given the limitations of the president's institutional resources, how realistic White House centralization could ever be. The normative debate focuses on whether greater presidential influence tends to produce sounder regulatory policy, however far that influence has or has not already come. The legal-constitutional argument considers whether the administrative state lacks constitutional legitimacy if the president has not or does not exercise considerable influence over agency decisionmaking: Constitutional defenders of the

rison, $O M B$ Interference with Agency Rulemaking: The Wrong Way to Write a Regulation, 99 Harv L Rev 1059, 1061 (1986) (acknowledging the executive's "complete dominance of the [administrative] rulemaking process under the Reagan Administration").

3 See generally Cynthia R. Farina, Undoing the New Deal through the New Presidentialism, 22 Harv J L \& Pub Pol 227 (1998) (arguing that strong executive control over the regulatory state threatens the legacy of the New Deal); Peter L. Strauss, Presidential Rulemaking, 72 Chi Kent L Rev 965, 967-68 (1997) (suggesting that executive control over the administrative rulemaking process impermissibly blurs the line between executive and lawmaker).

4 See Robert V. Percival, Presidential Management of the Administrative State: The NotSo-Unitary Executive, 51 Duke L J 963, 966 (2001) (arguing that the executive lacks the institutional resources and authority to effectively control agency rulemaking); Mark Seidenfeld, $A$ Big Picture Approach to Presidential Influence on Agency Policy-Making, 80 Iowa L Rev 1, 1317 (1994) (outlining the practical limits on OMB's and the president's ability to control agency policy); Strauss, 72 Chi Kent L Rev at 967-68 (cited in note 3) (discussing presidential willingness to engage in policy-based rulemaking, and the possible erosion of the political society such rulemaking might create).

5 See Shane, 48 Ark L Rev at 161 (cited in note 2) ("[D]oes government function best when the President enjoys plenary authority over the entire policy output of the bureaucracy?"); Seidenfeld, 80 Iowa L Rev at 3 (cited in note 4) (arguing against White House "micromanagement" of administrative rulemaking based on policy outcomes); Sidney A. Shapiro, Political Oversight and the Deterioration of Regulatory Policy, 46 Admin L Rev 1, 19-26 (1994) (analyzing the effects of executive oversight on democratic accountability and comparative expertise and experience). 
"unitary executive" thesis argue that but for substantial presidential control, the administrative state lacks constitutional grounding.

This general debate over the strong president can be linked-in fact on a deeper level is closely tied-to competing general visions of regulatory government. That is, one's position with respect to whether greater presidential control over agencies is desirable or even possible depends in part on one's underlying vision of the regulatory state. For example, those who find merit in the pluralistic "interest representation" model of regulatory government might be especially troubled by White House centralization to the extent that greater presidential control upsets the more or less benign dynamics of interest-group competition in other administrative decisionmaking fora. ${ }^{7}$ Of course, that worry depends on exactly what increased presidential control looks like. If greater White House centralization in practice entails correcting for interest-group imbalances in the legislative or administrative spheres, then a proponent of interest-group pluralism might instead welcome recent trends. For another example, one who views the regulatory state largely as an institution that delivers socially harmful rents to powerful interest groups might be inclined to favor greater presidential control (that is, to the extent presidential control makes it harder rather than easier for agencies to deliver rents to favored groups). In short, the debate over the strong president is deriva-

6 See Steven G. Calabresi, Some Normative Arguments for the Unitary Executive, 48 Ark L Rev 23, 37-47 (1995) (arguing that a "unitary executive" is necessary to maintain the Constitution's separation of powers, and to preserve the Framers' vision of an energetic and accountable president); Steven G. Calabresi and Saikrishna B. Prakash, The President's Power to Execute the Laws, 104 Yale L J 541, 550 (1994) ("[T] for the unitary Executive, taken together, firmly establish [the validity of] the theory."); Lessig and Sunstein, 94 Colum L Rev at 85-106 (cited in note 1) (supporting the "unitary executive" thesis as a matter of present constitutional interpretation, but suggesting that the thesis cannot be defended using an original understanding of the executive branch); David B. Rivkin, Jr., The Unitary Executive and Presidential Control of Executive Branch Rulemaking, 7 Admin L J Am $\mathrm{U} 309,317-20$ (1993) (contending that an original understanding of the Constitution supports the "unitary executive" thesis, because the Framers understood that "the Vesting Clause of Article II did place the totality of executive power with the President").

7 See, for example, Cynthia R. Farina, The "Chief Executive" and the Quiet Constitutional Revolution, 49 Admin L Rev 179, 185 (1997):

What our Constitution made ... was the judgment that "We, the People" would govern ourselves through the confluence of three very different voices: the House, the Senate, and the President. When one of these voices becomes the preeminent arbiter of our national will, I am not sure we are going to like what we hear.

See also Strauss, 72 Chi Kent L Rev at 984 (cited in note 3) (arguing that rulemaking is best performed by "agency heads whose limited field of action and embeddedness in a multi-voiced framework" represents a broader array of interests than the President alone); Seidenfeld, 80 lowa L Rev at 3 (cited in note 4) (concluding that White House "micromanagement" of rulemaking is "ineffective and even counterproductive"). For a classic formulation of the "interest representation" model, see Richard B. Stewart, The Reformation of American Administrative Law, 88 Harv L Rev 1667, 1723-47 (1975). 
tive of larger debates over the promise and performance of regulatory government. Greater or lesser presidential control is not desirable or undesirable in the abstract; the question rather is how such control operates within some larger picture of regulatory government.

This Article contributes to the debate over the strong president, or rather promotes it, by examining White House review of agency rulemaking over the past twenty years in practice, focusing especially on the Clinton administration. The effort here is partly descriptive: This Article explores how extensive White House review of rulemaking has been-how many rules the White House has reviewed, from which agencies, on what grounds, with what apparent levels of scrutiny, with what level of transparency, prompted by whom, and finally with what result. At the same time, however, this empirical inquiry is situated with reference to the debate over the strong president and, just as importantly, debates the successes and failures of regulatory government more generally. The data here thus facilitate evaluation of competing claims about the merits of a strong regulatory president and competing visions of regulatory government (though given the limited focus of this Article those evaluations will of course be incomplete). Last but not least, this Article argues that greater White House influence on agency rulemaking is, on balance, a welcome development in administrative law.

Part I first lays the groundwork by explaining the form and scope of White House review of agency rulemaking over the last two decades. Surveying competing claims that participants in the debate over the strong president make, Part I connects some of those claims to broader theories of regulatory government. Part II provides an empirical analysis of White House review of agency rulemaking from 1981 to 2000, focusing on the period from 1993 to 2000, and highlighting EPA rules in particular. Part II reports descriptive and inferential statistics found in or derived from publicly available but previously unmined sources of data. Part III returns to the debates concerning the strong president and regulatory government, considers whether and to what extent the findings of Part II provide support for competing views, and ultimately supplies a qualified defense of the strong regulatory president.

\section{WhITE HOUSE OVERSIGHT AND REGULATORY GOVERNMENT}

\section{A. Activist White House Oversight of Agency Rulemaking}

In early 1981, President Ronald Reagan issued his famous Executive Order number 12291. ${ }^{\mathrm{B}}$ Among other things, Executive Order 
12291 required agencies to submit to the Director of the Office of Management and Budget ("OMB") a "Regulatory Impact Analysis" for all of their "major" rules.' Executive Order 12291 defined "major" rule as any rule likely to: (1) have an annual effect on the economy of $\$ 100$ million or more; (2) impose a major increase in costs or prices for consumers, industries, government agencies, or geographic regions; or (3) have a significant adverse effect on competition, employment, investment, productivity, or innovation..$^{10}$ For such rules, agencies' regulatory impact analyses had to provide an assessment of the costs and benefits, a calculation of a rule's net benefits, and a description of alternative courses of action that might achieve the same regulatory goal together with an explanation of the reasons why those alternatives, if cheaper, could not legally be adopted. "Executive Order 12291 further required agencies to submit regulatory impact analyses twice, once accompanying a given "proposed" form and, following the notice-and-comment period, once again for the pending "final" version of the same rule. Such analyses would allow the White House, through the Director of OMB acting under the direction of the "Presidential Task Force on Regulatory Relief," to approve or seek changes in all major rules. Finally, Executive Order 12291 also required agencies to publish their regulatory agendas for each year, and to initiate reviews of all of their rules currently in effect. ${ }^{13}$

In early 1985, President Reagan, following his reelection, issued Executive Order number 12498, expressly "intended to complement the existing regulatory planning and review procedures" outlined in Executive Order $12291 .{ }^{14}$ Executive Order 12498 further solidified the Reagan White House's control, or assertion of control, over rulemaking agencies. Executive Order 12498 required agencies to submit to the Director of OMB a statement of their regulatory policies, goals, and objectives for each year. ${ }^{15}$ The order also required agencies to ensure that such plans were consistent with the goals of the agency "and of the Administration," including "the Administration's regulatory principles." ${ }^{.16}$ Together, Executive Orders 12291 and 12498 went far, at least by design, to make the Reagan White House a central part of the process of agency rulemaking. Agencies now had to obtain OMB

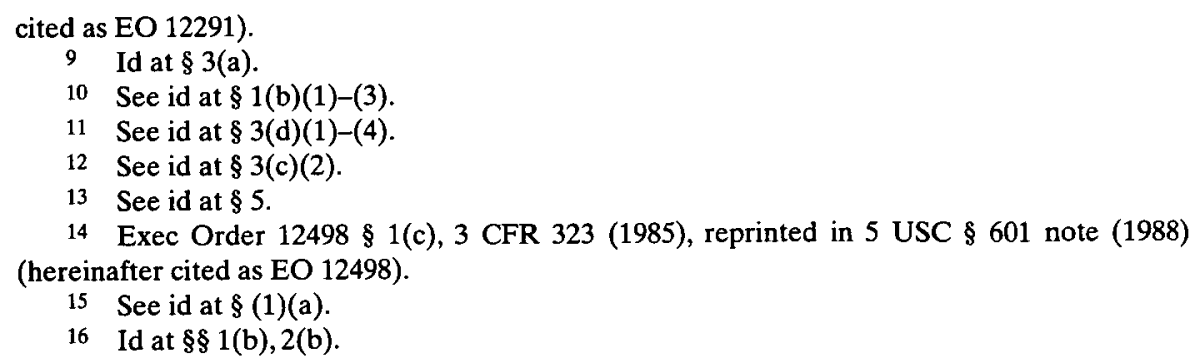


clearance for their major rulemaking initiatives not once but twice during a rule's development, and furthermore had to provide advance notice to the White House of regulatory initiatives in the form of annual reports of their regulatory intentions. Wherever the White House believed an agency's regulatory impact analysis did not justify its rule, the White House could require the agency to change if not abandon its rule. Little wonder that the orders have often been characterized as one of the most significant developments in administrative law of the 1980 s. ${ }^{17}$

Not surprisingly, White House review of rulemaking by the Reagan administration, and later by the administration of President George H.W. Bush, who preserved the Reagan orders, had its critics (as well as its defenders). ${ }^{18}$ The critics complained that OMB oversight was merely a front for deregulation - that the Reagan and later the Bush White House were hostile to regulation generally, and that they therefore used the institution of OMB oversight to stymie agencies' regulatory initiatives. Critics further complained that OMB oversight was clandestine, and thereby provided a very friendly decisionmaking forum for business interests that were against regulation. Critics also argued that OMB was at least co-opted and perhaps upstaged by the deregulatory initiatives of the Task Force on Regulatory Relief and the Council on Competitiveness, headed during the Reagan-Bush era by Vice Presidents George Bush and Dan Quayle, respectively. Concerning the regulatory impact analyses required under Executive Order 12291 in particular, critics argued that the methodology was little more than a guise for deregulation given that the costs of regulation would be easy to quantify while benefits, less easily quantified, would be unduly discounted or left out of OMB's cost-benefit calculus entirely.

During the first year of his first term, President Clinton revoked Executive Orders 12291 and 12498 , a move widely anticipated given their infamy among enemies of cost-benefit analysis and friends of regulation. Yet, surprisingly to some, Clinton replaced the Reagan orders with his own, Executive Order number 12866, which resembled

17 See, for example, Pildes and Sunstein, 62 U Chi L Rev at 3 (cited in note 1); Strauss and Sunstein, 38 Admin L Rev at 185 (cited in note 1).

18 See, for example, E. Donald Elliott, TQM-ing OMB: Or Why Regulatory Review under Executive Order 12,291 Works Poorly and What President Clinton Should Do about It, 57 L \& Contemp Probs 167, 175-81 (1994) (criticizing executive oversight of agency decisionmaking as a poor form of quality management); Morrison, 99 Harv L Rev at 1064 (cited in note 2) ("Contrary to the ostensible aim of the original Executive Order [12291], the system of OMB control imposes costly delays that are paid for through the decreased health and safety of the American public."); Erik D. Olson, The Quiet Shift of Power: Office of Management \& Budget Supervision of Environmental Protection Agency Rulemaking under Executive Order 12,291, 4 Va J Nat Resources L 1, 28-40 (1984) (arguing that executive review of agency rulemaking is overly secretive, and therefore detrimental to both public participation and effective judicial review). 
the Reagan orders in many crucial ways. ${ }^{19}$ Like Executive Order 12291, Clinton's executive order required an assessment of the expected costs and benefits of agencies' major rules. ${ }^{20}$ And like Executive Order 12498, the Clinton order required agencies to submit their regulatory plans and agenda, in addition to pending major rules, to OMB - or more specifically, to OMB's Office of Information and Regulatory Affairs ("OIRA"), identified by Executive Order 12866 as OMB's "repository of expertise concerning regulatory issues." Thus the Clinton order embodied both the substantive and procedural aspects of the Reagan orders-imposing cost-benefit criteria for major rules and designating OMB as the central overseer and clearinghouse for agency rulemaking. Executive Order 12866 also contemplated a central role for the vice president in overseeing agency decisionmaking, much as previous vice presidents had in the Reagan and Bush administrations, though now within a formally established framework. $^{22}$

With respect to the scope of Clinton's reincarnation of the Reagan orders, Executive Order 12866 applied to all "significant regulatory action[s]," defined as any regulatory action "likely to result in a rule" that would: (1) have an annual effect on the economy of $\$ 100$ million or more, or adversely affect the economy or a sector of the economy, productivity, competition, jobs, the environment, public health or safety, or state, local, or tribal governments or communities; (2) create a serious inconsistency or impede action taken by another agency; (3) materially alter the budgetary impact of entitlements, grants, user fees, or loan programs; or (4) raise novel legal or policy issues arising out of legal mandates, the president's priorities, or the principles of Executive Order 12866. ${ }^{23}$ Like Executive Order 12291, the Clinton order distinguished between rules that met the criteria for significance because they would have an annual impact on the economy of $\$ 100$ million or more, on the one hand, and rules that met the significance criteria for any other reason, on the other. For the first category of significance (in other words, economically significant rules), Executive Order 12866 required agencies to provide a detailed assessment, including all "underlying analys[e]s," of the expected benefits and costs of their action, as well as an account of the costs and benefits of all reasonably feasible alternatives to the proposed ac-

19 Exec Order 12866, 3 CFR 638 (1993), reprinted in 5 USC $\$ 601$ note (Supp 1993) (hereinafter cited as EO 12866).

20 See id at $\$ \$ 1,6$.

21 Id at $\S 2(\mathrm{~b})$. See also id at $\S 6(2)$ (outlining OIRA's central role in implementing the Order).

22 See id at $\$ \S 2(\mathrm{c}), 7$.

23 Id at $\$ 3(f)(1)-(4)$. 
tion and why those alternatives were not pursued. ${ }^{24}$ For all other categories of significance (in other words, non-economically significant rules), however, Executive Order 12866 merely required agencies to provide a summary of the potential costs and benefits of their rules, as well as a statement explaining how a given rule was consistent with a statutory mandate and with the president's priorities while avoiding undue interference with state, local, and tribal governments. ${ }^{25}$ The Order did not require agencies to provide the underlying analyses upon which their calculations of expected benefits and costs were derived. In other words, whereas Reagan's Executive Order 12291 required regulatory impact analyses for all categories of "major" rules as defined in that order, Clinton's Executive Order 12866 focused on the $\$ 100$ million threshold by requiring extensive cost-benefit analysis only for economically significant rules and only summary review for all other species of significant rules. ${ }^{26}$

While important similarities outnumbered important differences, Executive Order 12866 did depart from the Reagan orders in several noteworthy respects. For example, intending to "assure greater openness and accountability in the regulatory review process," the Clinton order limited receipt of oral communications "initiated by persons not employed by the executive branch of the Federal Government" regarding a rule under review to the Administrator of OIRA. ${ }^{27}$ The order furthermore required OIRA publicly to disclose information about communications between OIRA personnel and any person who is not employed by the executive branch, and to maintain a publicly available communications log containing the status of all regulatory actions, a notation of all written communications between OIRA personnel and outside parties, and the dates and names of individuals participating in all substantive oral communications, including meetings and telephone conversations, between OIRA personnel and outside parties. ${ }^{28}$ Executive Order 12866 also made clear that enhancing public health and safety, protecting the environment, and reducing discrimination were to be counted on the benefit side of the ledger when calculating a rule's costs and benefits. ${ }^{29}$ In short, Executive Order 12866 sought to preserve the basic methodology and institutional structure of the Reagan orders but to avoid the criticisms they met, particularly with respect to openness and the inclusion of intangible benefits in the cost-benefit calculus. Most fundamentally, however, the

\footnotetext{
Id at § 6(a)(3)(C)(i)-(iii).

See id at $\S 6(a)(3)(B)(i)-(i i)$.

Id at $\S 3(f)(1)-(4)$.

Id at $\S 6(\mathrm{~b})(4)(\mathrm{A})$.

See id at $\$ 6(b)(4)(B)(i i i),(C)$.

See id at $\S 6(a)(3)(C)(i)$.
} 
Clinton order embraced both the general principles of cost-benefit analysis, instructing agencies to select regulatory approaches that "maximize net benefits," ${ }^{30}$ just as Executive Order 12291 did, and the centrality of the White House itself to the rule-planning and rulemaking process, just as Executive Order 12498 did.

Immediately following the issuance of Executive Order 12866, the Director of OMB sent a memorandum to all "heads of executive departments and agencies, and independent regulatory agencies," stating that OIRA would have "primary responsibility" under the order for a number of "specific regulatory review and planning functions." The Director's memorandum also explained that the Administrator of OIRA had prepared a detailed memorandum, dated the same day and attached to his own, providing specific guidance on how Executive Order 12866 should be implemented. ${ }^{32}$ The OMB Director urged agency heads to give the Administrator's memorandum immediate attention. Among other things, the Administrator's implementing memorandum made clear that one of the purposes of Executive Order 12866 was "greater selectivity in the regulations reviewed by OIRA." ${ }^{33}$ Accordingly, the Administrator directed agencies to focus on the distinction between "economically significant" and otherwise "significant" rules, and to provide OIRA with more detailed information concerning the former. The Administrator also explained that OIRA would place in its public reading room a list of all meetings and telephone conversations between OIRA and the public or Congress during which the substance of a rule under OIRA review was discussed. $^{34}$ In addition, the Administrator explained that parties outside of the executive branch of government should communicate their concerns to the rulemaking agency before meeting with OIRA, and that OIRA would invite "policy-level officials" from the issuing agency to all such meetings."

Focusing on the details of White House oversight leads directly to questions about how such developments fit into a more general ac-

30 Id at $\$ 1(a)$.

31 Executive Office of the President, Office of Management and Budget, Leon E. Panetta, Director, Memorandum for Heads of Executive Departments and Agencies, and Independent Regulatory Agencies, Guidance for Implementing EO 12866 (OMB Memorandum M-94-3, Oct 12, 1993).

32 See id.

33 Executive Office of the President, Office of Management and Budget, Sally Katzen, Administrator, Office of Information and Regulatory Affairs, Memorandum for Heads of Executive Departments and Agencies, and Independent Regulatory Agencies, Guidance for Implementing EO $12866 \S 6$ (Oct 12,1993), reprinted in Office of Information and Regulatory Affairs, Report on Executive Order No 12866, Regulatory Planning and Review, Attachment 3, 59 Fed Reg 24276, 24290 (1994).

34 OMB Memorandum M-94-3 (Oct 12, 1993) (cited in note 31).

35 Id at $\$ 7$. 
count of regulatory government. Is "activist" White House review best understood as a legitimate and even desirable exercise of the president's power to carry out the execution of the laws in the manner most consistent with his own regulatory priorities? Or does the institution raise concerns about excessive concentration of regulatory power? On the former account, activist White House oversight may be a useful vehicle for the president to monitor his subordinates, thereby reducing principal-agent slack between the White House and the many agencies. On the latter account, in contrast, such review may be an unfortunately effective tool for the White House to provide favorable regulatory treatment to presidential constituencies, thereby undermining not only agency autonomy but possibly congressional intent as well. The following Part briefly considers alternative accounts of activist White House control over agency rulemaking.

\section{B. Activist White House Oversight and the Strong-President Debate}

As mentioned, what increased attention to agency rulemaking by recent presidential administrations implies about the structure of administrative government, and whether those implications are welcome or unwelcome in the interest of promoting desirable regulatory outcomes is a matter of controversy. Proponents of expanded White House control defend greater control over agency rulemaking on several grounds. First, such control promotes consistency across the executive branch. ${ }^{36}$ Because the president is uniquely situated to review pending rules of all agencies, the White House is able to identify, and avoid, rules from one agency that either work at cross-purposes to, or are redundant with, rules of another agency. Here White House review serves a good-government, coordination purpose.

Furthermore, while OMB is not an expert in any substantive regulatory field, it has become an expert in the field of regulation itself. $^{37}$ Accordingly, OIRA has developed a special institutional capacity for distinguishing between, on the one hand, regulation likely to advance sound regulatory policy, and on the other, regulation that however well intentioned - may lead to unintended and undesirable consequences. In addition to mere coordination, in other words, White House review provides a "quality check" on pending rules. On this view, OIRA's small size and technocratic orientation are important

36 See, for example, DeMuth and Ginsburg, 99 Harv L Rev at 1081-82 (cited in note 2) (arguing that centralized review of proposed regulations encourages policy coordination, greater political accountability, and more balanced regulatory decisions).

37 See, for example, id at 1084. 
virtues. ${ }^{38}$ Centralized expertise offers a needed antidote to the topsyturvy world of congressional and bureaucratic regulatory politics.

Defenders of greater White House control further argue that the president is uniquely situated to advance national interests, as opposed to the factional interests that are often promoted by Congress, and that consequently find expression in agency decisions. ${ }^{39}$ According to this argument, presidential control over agencies is desirable, even necessary, because it promotes evenhandedness in regulatory decisionmaking. Because the president's constituency is a national one, the president can best aggregate and balance competing interests in the course of developing sound regulatory policy. Greater presidential control is desirable not merely because it avoids inconsistencies, redundancies, and unintended consequences in agency rulemaking, but more importantly because it helps to ensure that all relevant interests are identified and counted. According to one variation of this view, OIRA's specialized institutional focus might also promote reasoned deliberation about regulatory alternatives more effectively than other, more cumbersome, regulatory institutions. ${ }^{40}$ Either way, presidential oversight tends to promote the general welfare.

Another version of the argument in favor of a strong president, the unitary executive thesis, insists that presidential control over agencies is necessary not just to promote a national orientation in agency rulemaking, but also to preserve the political and constitutional legitimacy of the regulatory state. ${ }^{41}$ In the absence of presidential control, there are insufficient checks on agency decisionmakers. Agencies might advance their own visions of good regulatory policy, but, electorally unaccountable, those visions lack political legitimacy. No less importantly, because the Constitution contemplates that the executive power of the United States resides in the president, agencies not closely overseen by and answerable to the president lack con-

38 See, for example, id at 1083 ("The OMB staff is rarely able to bring new knowledge of a field to the attention of the agency. Yet the OMB staff is routinely able to ask hard questions ... to which an agency should be expected to have good answers before it proceeds to regulate.").

39 While arguing against "micromanagement" by the OMB of every particular agency decision, Mark Seidenfeld adopts a middle position, advocating instead a "big picture" approach to White House oversight according to which the White House should exert a strong influence on administrative policy by advancing broad regulatory goals informed by the president's overarching vision of public-interested regulatory policy. See Seidenfeld, 80 Iowa L Rev at 1, 25-30 (cited in note 4). See also DeMuth and Ginsburg, 99 Harv L Rev at 1079-82 (cited in note 2) (arguing that greater presidential oversight promotes national interests the President is especially positioned to promote).

40 See, for example, DeMuth and Ginsburg, 99 Harv L Rev at 1079-81 (cited in note 2) (suggesting that OMB was created in order to "impose order on the rulemaking process").

41 See Calabresi and Prakash, 104 Yale L J at 568-69 (cited in note 6) (arguing that administrative power cannot constitutionally exist except as a subset of the president's executive power). 
stitutional moorings. ${ }^{42}$ Activist White House oversight thus is not only desirable but necessary to preserve the constitutional legitimacy of the regulatory state.

But critics see trouble with activist White House oversight. For one, they see greater presidential control over agencies as unrealistic. While the White House may exert control over particular agency decisions from time to time, scarcity of presidential resources limits the extent to which the president can effectively monitor-much less influence-most agency decisions. " Inevitably, substantial agency autonomy is a fact of regulatory life. Presidential control, therefore, will tend to be ad hoc and politically motivated, not based entirely on a deep understanding of the relevant regulatory issues.

The argument continues that to the extent White House control is possible, it is undesirable. This is true because greater White House centralization upsets a balance between law and politics already struck by the legislature and reinforced by the courts. ${ }^{44}$ By this account, activist presidential oversight is meddlesome, for Congress delegates regulatory power to agencies, not to the president, and while the president is charged with executing the law, that constitutional charge does not justify presidential reshaping of agencies' regulatory initiatives. With respect to agency rulemaking in particular, critics of greater presidential control have argued that the president should not "behave[] as if rulemakings were his rulemakings." In addition, where the president and an agency disagree in a particular case, the president should not simply rely on his removal power to insist that the agency yield. Instead, the agency, Congress's delegatee, should carry the day. Where agencies go astray by failing to follow

42 See id.

43 See, for example, Seidenfeld, 80 lowa L Rev at 14-15 (cited in note 4) ("OMB does not have the personnel or resources to develop the knowledge or the data necessary to analyze independently most agency proposed rules. ... In short, the same shortcomings that result from congressional committees' needs for information also plague OMB review and limit the efficacy of such review.").

44 See, for example, Strauss, 72 Chi Kent L Rev at 967-68 (cited in note 3) (discussing the "tension inherent in the Constitution between Congress's power to create the instruments of government .... and the fact of a single chief executive at the head of the agencies thus created"); Thomas O. Sargentich, The Administrative Process in Crisis-The Example of Presidential Oversight of Agency Rulemaking, 6 Admin L J Am U 710, 713-15 (1993) (paraphrasing a portion of Justice Stevens's opinion in Chevron USA Inc v Natural Resources Defense Council, Inc, 467 US 837 (1984) - "deference to an agency's construction of its statute makes sense in significant measure because agencies are accountable to the President"-as evidence of judicial approbation of the then-present balance of power between the president and the regulatory state).

45 Strauss, 72 Chi Kent L Rev at 984 (cited in note 3).

46 See id at 983-84 (arguing that administrative agencies are delegated authority by Congress to implement regulatory laws, and the president should only see that the duties of the agencies are faithfully performed). 
congressional intent, courts or, if necessary, Congress itself can correct for agency waywardness. Where, on the other hand, Congress has left room for agency discretion, that discretion should not be replaced by presidential prerogative.

The strongest form of this argument goes farther, alleging that greater White House control not only improperly reallocates regulatory power away from Congress and agencies, but more ominously provides the White House with a means to deliver regulatory benefits to politically important constituencies at the expense of the general welfare." According to this view, the president is accountable not to national interests, but to influential interests with much more at stake. ${ }^{48}$ Thus, interest groups that did not get everything they wanted in the legislative and administrative arenas find in the White House review process yet another forum to advance their goals. By appealing to the White House to scrutinize what are for them undesirable regulatory decisions, powerful interest groups might see their regulatory preferences realized after all, thus upsetting whatever compromises were reached in the legislative and administrative processes.

What is worse, because the review process is opaque, the White House is able to provide regulatory favoritism to its important constituencies without attracting much notice, which provides opportunity for the White House to benefit those constituencies even where doing so is undesirable from the perspective of sound public policy. In other words, the absence of transparency associated with White House control means the president can reap political benefits without incurring the political costs that would come with well-publicized regulatory favoritism. On this view, the president not only has no special claim to represent national interests, but also is motivated and well positioned to advance his own.

\section{The Strong-President Debate and Theories of Regulatory Politics}

As all of this implies, alternative accounts of the strong president are ultimately linked to larger competing visions of regulatory politics, and can be fully understood only with reference to those broader visions. That is, those who see greater presidential control as benign

47 See, for example, Morrison, 99 Harv L Rev at 1065 (cited in note 2) ("The Administration has principally used the system of OMB review created by the Executive Orders to implement a myopic vision of the regulatory process which places elimination of cost to industry above all other considerations. In doing so, however, the Administration has imposed a significant price on the public....").

48 See id.

49 Id at 1067 ("[A] fundamental difficulty with the review process is that it operates in secrecy... OMB provides information and misinformation to agencies and applies criteria for deciding whether to approve a rule that never appear[s] in the public record.... OMB is principally recycling industry arguments that proved unsuccessful at the agency level."). 
tend to see the outcome of unsupervised agency rulemaking as itself problematic. For example, agency rulemaking in the absence of active White House oversight is undesirable because agencies are too easily captured by the regulated interests they represent. According to one familiar formulation, agencies are ever worried about their budgetary health as well as the scope of their regulatory jurisdiction, and for those reasons must be overly solicitous of the preferences of members of Congress, who after all control agency budgets and define the boundaries of agency authority. ${ }^{50}$ For their part, members of Congress must satisfy the regulatory preferences of their powerful constituencies, who provide electoral resources necessary for a member to remain in office. Thus, are legislators motivated to encourage agencies to provide favorable regulatory treatment to important constituencies, or even to insist that agencies do so?

But the story need not be quite so jaundiced to support the same worry about presidentially unsupervised agency decisionmaking. According to one variation of the agency capture thesis, for example, agencies may well be able to resist the most direct and political forms of interest-group capture, but may nevertheless be co-opted by interest groups because they depend on those groups for so much of the information on which their regulatory decisions rest. ${ }^{51}$ This "informational capture" thesis assumes that agencies may seek to provide general-interest regulation, and even that Congress has too few devices to monitor agencies and discipline them for failing to favor unworthy congressional constituencies. But because agencies rely so heavily on information about the consequences of regulatory alternatives from the very interests most affected by regulation, who therefore know the most about those consequences, agencies over time become unwittingly biased in favor of those they regulate. To the extent there is a "revolving door" for employment between agencies and regulated interests, ${ }^{\mathrm{s2}}$ the informational bias becomes worse.

50 See Steven P. Croley, Public Interested Regulation, 28 Fla St U L Rev 7, 11-12 (2000) (summarizing the view that agencies respond to Congress to preserve their statutory authority and budget).

51 See, for example, Clayton P. Gillette and James E. Krier, Risks, Courts, and Agencies, 138 U Pa L Rev 1027, 1067 (1990) (noting that private interests often gain agency access by providing useful information, and that if "some groups enjoy a comparative advantage in catering to administrative needs and desires ... there arises the danger that agency attention will be captivated by too narrow a range of interests and be diverted from an appropriately public perspective"). For a classic statement of the information capture thesis, see Marver H. Bernstein, Regulating Business By Independent Commission 86-90, 155-60 (Princeton 1955) (arguing that once an agency reaches a "period of maturity," that agency loses mainstream political support, and consequently loses the ability "to extend regulation beyond the limits acceptable to the regulated groups").

52 See generally William T. Gormley, Jr., A Test of the Revolving Door Hypothesis at the FCC, 23 Am J Polit Sci 665, 666-67, 681 (1979) (defining the "revolving door hypothesis" as the 
While the president too is subject to his own set of interest-group pressures, the president's office and his institutional resources allow him to transcend the forms of interest-group capture to which agencies are so susceptible. ${ }^{53}$ Presidential oversight is advantageous, then, because the president does not depend on Congress as agencies do. Instead, the president is largely above the interest-group fray. Certainly the president is not commonly susceptible to the regional faction that often motivates legislators and, therefore, agencies.

True enough, a given president may be especially friendly to certain kinds of interests-business interests, for example, or environmentalists - for ideological or even political reasons, but presidential capture is much less feasible relative to agency capture for even the most powerful interest groups. The president therefore has the luxury to advance the interests of ordinary citizens whose interests, because their individual stakes are so small, ${ }^{, 4}$ are not well represented by legislators or agencies. Better still, the president can use the unequaled visibility of his office to take credit before the citizenry for his vindication of their general interests. As a result, the president can compensate for common pathologies of regulatory decisionmaking resulting from agencies who otherwise take too many cues from legislators and legislators' interest-group supporters.

Critics of expanded presidential oversight of agency rulemaking imply a more favorable view of agency and possibly even of legislative decisionmaking. Their view finds support, for example, from the traditional picture of agencies as experts whose primary function is not to deliver favorable regulation to politically powerful constituencies but rather to exercise their expertise in a rational way that promotes the general welfare. ${ }^{\text {ss }}$ According to this picture, Congress dele-

influence exerted on regulatory agencies by regulatory commissioners formerly employed by regulated industries, and using empirical data to conclude that "the appointment of a former employee of a regulated industry to a regulatory agency does increase the likelihood of decisions favorable to the regulated industry").

53 See, for example, Lessig and Sunstein, 94 Colum L Rev at 93-106 (cited in note 1) (discussing several theories of regulation, and concluding that the neopluralist theory, the civic republican theory, and to some extent, the public interest theory of regulation predict that executive oversight of agency rulemaking would alleviate capture concerns); Calabresi, 48 Ark L Rev at 83 (cited in note 6) (defending the "unitary executive" thesis as a solution to "the well known problem of agency capture").

54 See generally George J. Stigler, Can Regulatory Agencies Protect the Consumer?, in George J. Stigler, The Citizen and the State: Essays on Regulation 178, 186-87 (Chicago 1975) (arguing that the consumer "is the victim without recourse of our political system which is inaccessible to groups that may be large but whose members as individuals have only small stakes in a controversy"); George J. Stigler, The Theory of Economic Regulation, 2 Bell J Econ \& Mgmt Sci 3, 10-11 (1971) (noting the considerable transaction costs inherent in political participation, and arguing that when individual stakes in an issue are small, interest groups can easily obtain legislation counter to the public interest).

55 See, for example, Paul J. Quirk, Industry Influence in Federal Regulatory Agencies 5 
gates rulemaking authority to agencies precisely because agencies have the institutional capacity to develop well-informed responses to regulatory problems. Congress strikes whatever political balance it deems generally appropriate for the regulatory issue at hand, expressed in an agency's statutory mandate, and agencies take it from there, developing the specific information necessary to approach regulatory problems in a rational way.

And where agency decisions are not primarily the product of expert decisionmaking based on consideration of all relevant information, Congress and especially the courts are there to correct the problem. As agency legitimacy ultimately borrows from legislative legitimacy, given that agencies act pursuant to legislatively granted authority, it is the legislature's role to oversee agencies and ensure that agency decisionmaking reflects congressional will. Judicial review helps, for agencies acting contrary to the purposes of their authorizing legislation-for instance, acting beyond the scope of their delegated authority, or responding to considerations not reflected in or supported by an agency's decisionmaking record-are likely to have their decisions invalidated by courts.

It almost goes without saying that critics of strong presidential oversight need not and do not idealize agencies or Congress, or for that matter courts. Nor do critics imply that agency decisionmaking is entirely independent of undesirable political influences and considerations. But the point remains that if White House oversight is undesirable because it alters the equilibrium otherwise reached by agencies-exercising powers delegated by Congress and in anticipation of challenges to their actions in court-then it must be the case that that equilibrium is preferable to presidential alteration.

Presidential alteration is undesirable, on this view, precisely because it threatens agency autonomy and therefore agencies' ability to apply their expertise in a disinterested way. White House review, in other words, shifts regulatory decisionmaking power away from agencies and to the president, notwithstanding that, between the two, the president has far fewer institutional resources with which to develop

(Princeton 1981) (suggesting that agency decisions would ideally be made by objective analysis, free from heavy industry interference).

56 This image traces to Woodrow Wilson. See Woodrow Wilson, The Study of Administration, 2 Polit Sci Q 197, 217 (1887) ("The ideal for us is a civil service cultured and self-sufficient enough to act with sense and vigor, and yet so intimately connected with the popular thought, by means of elections and constant public counsel, as to find arbitrariness or class spirit quite out of the question.").

57 See 5 USC $\$ 706(2)$ (2000) (setting forth the scope of judicial review of agency action). See generally American Bar Association, Section of Administrative Law and Regulatory Practice, A Blackletter Statement of Federal Administrative Law, 54 Admin L Rev 17, 36-45 (2002) (explaining the standards of review of agency action). 
expertise about complicated regulatory problems. Granted, the president has the legal-constitutional power to direct agencies to exercise the discretion given to them by Congress, but the president will seldom know better than the agencies themselves how their discretion should be used. Consequently, regulatory decisions that reflect strong presidential oversight will tend to be based more on political and less on technocratic considerations.

Worse, strong presidential oversight also shifts power away from Congress and to the president, for by most acts of delegation Congress intends for agencies to apply their expertise in the course of exercising their discretion. Where instead Congress wants the president to have influence over particular decisions that agencies make, as opposed to agenda-setting influence in ordering their statutory priorities, Congress can so indicate by specifically delegating power to a White House agency. But in the normal course, Congress delegates regulatory power to agencies so that agencies, not the President, can exercise that power.

This is not to say that the choice between captured agencies and a beneficent president, on the one hand, and publicly interested agencies and a corrupted president, on the other hand, is a necessary choice. There is middle ground: Agencies may sometimes but not invariably be captured, and the president may sometimes but not always be overly solicitous of his own political constituencies and too inattentive to general interests. But now the argument for or against activist White House oversight depends on how that oversight operates, that is, whether in practice White House oversight tends more often to correct for captured agencies, or to provide a forum for interest-group rent seeking, or something else.

Finally, one might view agency decisionmaking as pathological, but view presidential oversight as similarly pathological. Strong presidential oversight once again may or may not be desirable, depending on whether it is worse than agency decisionmaking or instead, although similarly subject to interest-group politics, slightly less so relative to agency decisionmaking. Or, one might view agency decisionmaking as generally benign, in that for procedural reasons it promotes some minimal level of evenhandedness, ${ }^{58}$ but also view presidential oversight as a welcome development because it provides the president with opportunities to reinforce beneficial agency action and even to provide agencies with enough political support to withstand undesirable congressional influence, interest-group pressures, and capture. ${ }^{59}$

58 See generally Croley, 28 Fla St U L Rev at 84-92 (cited in note 50) (noting that many agencies regularly invite more public participation than required by law, and that the process of agency rulemaking usually ensures advocacy for the public interest).

59 See, for example, Kagan, 114 Harv L Rev at 2335 (cited in note 1) ("[B]ecause the 
Strong White House oversight may be desirable, but only provided that it works to strengthen rather than to undermine agencies' political position vis-à-vis Congress and congressional constituencies.

\section{Pro and Con Activist White House Oversight: Competing Predictions}

In short, whether greater White House oversight ameliorates or exacerbates underlying defects in regulatory decisionmaking processes depends on exactly what that oversight actually looks like, as well as on just what regulatory decisionmaking in the absence of presidential oversight looks like. Focusing on the former, defenders and critics of expanded White House control imply different predictions about the form that White House oversight takes. For example, proponents of a strong regulatory president would expect that the White House in fact has the institutional capacity to undertake meaningful, substantive review of pending agency rules. This in turn means that the White House should possess the human resources to conduct meaningful, substantive review of rules, and furthermore that White House reviewers possess the requisite understanding of the particular regulatory issues implicated by pending rules, or can gather such an understanding from the relevant rulemaking agency.

Second, defenders of activist White House oversight would predict that changes to rules required as a result of White House oversight should be based on the merits of the rule, according to some clearly established criteria, rather than on the White House's own political calculus. That is, whenever the White House requires a change in a rule, it does so with reference to ascertainable criteria, rather than to inscrutable considerations. Furthermore, whenever the White House requires a change in a rule, it should not do so unilaterally, but rather should provide the rulemaking agency with an opportunity to show how the proposed rule is appropriate given the agency's regulatory objectives and as evaluated according to established criteria.

Finally, to the extent that the White House is led to scrutinize rules under review due to objections from private parties, it should do

President has a national constituency, he is likely to consider, in setting the direction of administrative policy on an ongoing basis, the preferences of the general public, rather than merely parochial interests."); Lessig and Sunstein, 94 Colum L Rev at 3 (cited in note 1) ("A strongly unitary executive can promote important values of accountability, coordination, and uniformity in the execution of the laws."); Pildes and Sunstein, 62 U Chi L Rev at 8-10 (cited in note 1) (presenting strategies for efficient executive control of agency rulemaking, in part to combat."the influence of well-organized private groups with personal stakes in the outcome" of regulatory decisionmaking); Strauss and Sunstein, 38 Admin L Rev at 202-03 (cited in note 1) (arguing that the president has the authority to assert control over agency rulemaking, and that "he should exercise that power"). See also Stephen Breyer, Breaking the Vicious Circle: Toward Effective Risk Regulation 59-79 (Harvard 1993) (calling for centralized executive review of regulation). 
so in an evenhanded way, by entertaining objections from a wide range of interests and points of view. This expectation also has two components. One predicts that interest-group access to and influence with the White House is not imbalanced such that certain types of interests consistently see their objections to pending rules addressed while objections by other types of interests are ignored. Nor should White House review simply recreate the economic or regional factionalism that is often said to characterize regulatory decisionmaking at the legislative and administrative levels.

Skeptics of expanded White House control, on the other hand, would make an opposing set of predictions. The critical view would find support, for example, from a finding that the White House lacks the institutional capacity to undertake meaningful substantive review of pending agency rules. Specifically, on this view one would expect to find that the White House does not possess the human resources to conduct meaningful substantive review of rules, and that those engaged in rulemaking review lack the requisite understanding of the particular regulatory issues implicated by pending rules, and cannot reliably gather such understanding from the relevant rulemaking agency or elsewhere.

In addition - in part as a consequence - the critical view predicts that changes to rules required as a result of White House review are not based on the merits of the rule, according to established criteria, but rather on the White House's own political calculus. That is, when the White House requires a change in a rule, it does so not with reference to clearly established evaluative criteria, but rather due to its own inscrutable-that is, political and nontransparent-considerations. A critic would also expect that when the White House requires a change in a rule, it usually does so unilaterally, without providing the rulemaking agency with an opportunity to show how the rule as it stands is appropriate given the agency's regulatory objectives. Because political considerations are primary, the agency's regulatory mission is somewhat beside the point.

The critical view would furthermore predict that to the extent the White House is led to scrutinize rules under review due to outside objections to agencies' rules (rather than solely on its own initiative), it does so in a lopsided way by entertaining objections from some types of interests and points of view, and not others. In other words, interest-group access to and influence with the White House is not evenhanded. Rather, certain types of interests should consistently see their objections to pending rules addressed, while objections by other types of interests are ignored. White House review thus provides another forum for the economic and regional factionalism that may often characterize regulatory decisionmaking at the legislative and adminis- 
trative levels. In fact, a critic would predict, a lack of transparency at the White House level may well exacerbate the undesirable consequences of interest-group politics in the legislative and administrative arenas.

On the other hand, because the Clinton order reflected efforts to ensure the openness and evenhandedness that some argued White House review under the Reagan orders lacked, a defender of executive control might argue that White House oversight as carried out under Executive Order 12866 is especially easy to justify. Indeed, some contributors to the debate over the strong president have argued or hoped that, given the differences between Executive Order 12866 and the Reagan orders, presidential oversight under the Clinton administration might be especially likely to lead to sound regulatory decisionmaking. ${ }^{50}$ Conversely, a critic of greater executive control might argue that if White House oversight as carried out under Executive Order 12866 is still problematic, even though such oversight as implemented during the Clinton era may constitute a kind of "best case" for White House centralization given the openness requirements of that order, then a strong regulatory president is certainly undesirable.

Thus the issue is joined. Accordingly, Part II investigates White House control over agency rulemaking from 1981 to 2000, concentrating especially on the last seven years of that period. It does so in part simply because Executive Order 12866 increased transparency of White House oversight to some degree (whether enough to matter much is yet to be seen), thereby making systematic study more feasible. But the following analysis focuses on the Clinton White House also on the assumption that White House oversight from 1993 to 2000 provides a favorable case for greater presidential influence: Defenders of a strong regulatory president should be able to identify aspects of White House oversight during the Clinton era that bolster their position, otherwise one might seriously question whether greater presidential control is desirable after all. By the same token, critics should be able to point to features of White House oversight that confirm their fears, otherwise one might seriously question whether those fears are overstated and require qualification.

60 See, for example, Pildes and Sunstein, 62 U Chi L Rev at 19-24 (cited in note 1) (distinguishing between the disclosure requirements of the Reagan administration and the Clinton administration, and arguing that the Clinton "disclosure requirements are a healthy idea"); Seidenfeld, 80 Iowa L Rev at 44 (cited in note 5) ("Unlike under the Reagan program, [under the Clinton program] OIRA must respond to an agency submission within strict time limits; OIRA cannot 'pocket veto' a proposed rule by simply delaying review of it."); Shapiro, 46 Admin L Rev at 36-37 (cited in note 5) (noting that the Clinton administration's system of OIRA oversight "ends much of the secrecy that marked White House oversight in the two prior administrations"). 


\section{OIRA REVIEW OF AGENCY RULES: AN EMPIRICAL ANALYSIS}

A. The Institutional Framework

Given that White House oversight of agency rulemaking manifests itself institutionally in the form of OIRA review of pending rules, some background information about that office begins to shed light on the White House's expanded role in the rulemaking process. Originally created by the Paperwork Reduction Act of 1980, OIRA came to be the organizational locus for the White House's participation in regulatory decisionmaking at the "micro" level. ${ }^{61}$ OIRA is one of three divisions of the management side of OMB, and is divided into three offices, one of which, Regulatory Review and Paperwork, conducts rulemaking review. Although OIRA is not specifically mentioned in the Reagan orders, it performed regulatory review during the 1980 s as well. At that time it, to some degree, competed with vicepresidential task forces on regulation. Executive Order 12866 and its implementing directives, however, officially delegated to OIRA responsibility for all regulatory review, though under the supervision of the vice president and president.

OIRA's Regulatory Review and Paperwork office also is divided into three branches, "Natural Resources," "Commerce and Lands," and "Human Resources." These branches allocate responsibility for rulemaking review by subject matter of submitted rules. For example, the Natural Resources Branch reviews Environmental Protection Agency ("EPA") rules, while the Commerce and Lands Branch reviews rules from the Department of Transportation ("DOT"), and the Human Resources Branch reviews rules from the Occupational Safety and Health Administration ("OSHA") and from the Department of Housing and Urban Development ("HUD"). Each branch is headed by a "Branch Chief," who together oversee some twenty-five to thirty "desk officers." These desk officers perform the line-level rulemaking review. The Branch Chiefs answer to OIRA's Deputy Administrator, who in turn answers to the Administrator of OIRA, the agency's only political appointee, and whose appointment requires Senate confirmation. The Administrator answers to the Director of $\mathrm{OMB}$, as well as to the vice president and president.

Of the three Branch Chiefs who occupied that position at the close of the relevant study period, two were economists and one was a lawyer. OIRA's two-and-a-half-dozen desk officers, most of whom have advanced degrees, are trained in public policy, policy analysis,

61 See generally Seidenfeld, 80 Iowa L Rev at 3 (cited in note 5) (outlining the threat of "micromanagement" of agency rulemakings by OMB and proposing "big picture management" as a desirable alternative). See also Shapiro, 46 Admin L Rev at 24,38 (cited in note 5) (explaining White House "micromanagement"). 
economics, or statistics. Following a critical report in the early 1980s by OMB Watch, a public-interest watchdog group that monitors the $\mathrm{OMB}$, according to which desk officers were insufficiently trained and experienced to have an adequate understanding of the rules they reviewed, OIRA became more particular in its hiring practices and currently requires new desk officers to have advanced training in quantitative methods. While much of the OIRA review process focuses on cost-benefit analysis, as the professional training of OIRA's staff suggests, it should be emphasized that Executive Order 12866, like the Reagan orders before it, also contemplates that rules are to be reviewed for their compatibility with the president's regulatory principles and priorities more generally. ${ }^{62}$ On that subject, Executive Order 12866 provides that disagreements between OIRA staff and a rulemaking agency are to be resolved wherever possible by OIRA's Administrator, and in the event of an impasse-when, for example, an agency head is unyielding to OIRA - by the vice president or president directly. ${ }^{63}$ The order furthermore states that direct presidential and vice presidential involvement to resolve disputes between OIRA and an agency may be instigated only by the Director of OMB or by the head of an agency. ${ }^{64}$

In the typical case, OIRA desk officers receive rule submissions from agencies and initiate the review process. Agencies submit to OIRA an "Executive Order 12866 Submission" form accompanying their rules. The submission form, standardized by OMB, contains basic information about a submitted rule, including its stage of development and whether it is economically significant as defined by the Order. Agencies must also certify that a submitted rule complies with the substance of Executive Order 12866 with signatures of both the agency's designated regulatory contact person and the agency's relevant program official. The 12866 submission form must further contain contact information for a person at the agency "who can best answer questions regarding the content" of the submitted rule. ${ }^{65}$ Through the course of the review process, desk officers often communicate with the agency, focusing especially on the technical aspects of a given rule. Under the Clinton order, each agency has designated a "Regulatory Policy Officer," who serves as a liaison between OIRA staff and the head of the agency concerning that agency's submitted rules, further promoting communication between agencies and OIRA. Where

62 EO 12866 at $\S \S 1(\mathrm{~b}), 2(\mathrm{a}), 4(\mathrm{a}), 4(\mathrm{c})(1)(\mathrm{A}), 4(\mathrm{c})(\mathrm{s})$ (cited in note 19).

63 Id at $\$ 7$.

64 Id.

65 See Executive Order 12866 Submission Form, OMB \#83-R, online at http://www.whitehouse.gov/omb/inforeg/83r.pdf (visited May 19, 2003).

66 EO 12866 at $\S 6(a)(2)$ (cited in note 19 ). 
questions arise concerning a rule's compatibility with the president's political objectives, on the other hand, the Administrator of OIRA assumes a lead role in the review process. According to the data discussed in Part II.B, this entire review process took on average 25 days for rules reviewed under the Reagan orders, and 44 days for rules reviewed under the Clinton order. ${ }^{67}$ With these institutional facts in mind, the following Parts present an overview of rulemaking review by the White House over the past twenty years.

\section{B. Sources of Data}

Several sources of previously untapped information are used in this Article to investigate what White House review of agency rulemaking looks like in practice. First, the Regulatory Information Services Center ("RISC"), an office within the General Services Administration ("GSA"), maintains on behalf of OMB a comprehensive computer log summarizing every rule reviewed by OIRA. The logged information provided for each rule is sparse, but still contains several crucial pieces of information, including: the name of the rulemaking agency, a very brief description of the subject matter of the rule, an $\mathrm{OMB}$ and RISC identifying number, an indication of whether the rule submitted for review was a proposed or final rule, whether the rule was economically significant or not, the date OIRA received the rule and the date it completed its review, and finally an indication whether the reviewed rule was changed or instead approved by OIRA without change. The OMB's own website contains a small rolling piece of this log covering those rules for which OIRA completed its review from the present going backwards in time for thirty days. That thirty-day window is not large enough to provide very illuminating information about OIRA review, but hard copies of the entire RISC log-which can be organized alphabetically by agency and roughly chronologically according to the dates a given agency's rules were first submitted for review - are available from GSA for periods extending over several years.

Second, using its comprehensive log, RISC can also generate summary tables listing the total number of rules submitted for review by each agency for a given year (or any other time period), the number of those rules that were economically significant, and the number of the agency's rules that were changed and accepted without change. These summary tables supply no information about any particular rule, but nevertheless provide an overall picture of OIRA rulemaking review. One can also combine such tables to generate aggregate information about the number and type of rules (economically signifi-

67 See Appendix. 
cant or not) submitted by any agency for any period of time, as well as aggregate information about the proportion of an agency's rules that were changed and not changed during the review process.

In addition to information available through RISC, OIRA itself maintains a publicly available "meetings log" documenting every meeting between OIRA staff and any outside (that is, nongovernmental) person concerning any rule under submission (or expected to be under submission) at OIRA. As explained above, this meetings log is required by Executive Order 12866, reflecting an attempt to avoid one of the most common criticisms of White House oversight during the Reagan administration: that White House review provided an opportunity for powerful interest groups to enlist the White House to change rules outside of public scrutiny. The meetings log thus purportedly lists every meeting between OIRA staff and outside parties, identifying each meeting by date and a very short (and sometimes cryptic) reference to the rule under discussion. The log also lists the names and organizational affiliations of every party in attendance at each meeting. Finally, OIRA also keeps on file any written materials supplied by parties meeting with OIRA staff. ${ }^{68}$ These written materials range in length and specificity from short statements identifying the party who requested a meeting to detailed criticisms of the rule that is the subject of a meeting.

The analysis here employs all of these sources of available data about OIRA rulemaking review. The RISC tables allow for comparisons of rulemaking review both across time and across agencies. One can examine, for example, whether the absolute number or percentage of reviewed rules that were changed increases or decreases from the Reagan-Bush era to the Clinton era. One can also examine, for example, which agencies' rules are especially likely to be changed as a result of the review process, over any given period of time. The comprehensive RISC log can be used, in tandem with the OIRA meetings $\log$, to trace the fate of individual rules. Because meetings in the OIRA meetings log are dated, it is possible (in most cases) to find the particular rule subject to an OIRA meeting in the RISC rule log too, and thus to ascertain the rule's stage and, more importantly, whether it was changed during the review process. The OIRA meetings log itself is an important source of information as well. Because it lists the names and organizational affiliations of persons in attendance at a meeting, it is possible to code the types of interests represented at a meeting and, more generally, to learn something about what kinds of

68 This requirement followed $\S 6(\mathrm{~b})(4)(\mathrm{C})(\mathrm{ii})$ of Executive Order 12866. From 1993 through 1999, OIRA maintained accessible files that contained written materials supplied by outside parties who sought a meeting concerning a rule under review. Inexplicably, OIRA seems to have discontinued that practice in mid-1999. 
interests are typically represented at an OIRA meeting, as well as about what kinds of rules are most commonly the subject of OIRA meetings.

In addition, again using the RISC log together with the OIRA meetings $\log$, it is possible to examine whether rules that were the subject of meetings with certain types of interest groups are more or less likely to be changed during the review process relative to rules that were the subject of meetings with other types of interests. For instance, one can determine whether environmental rules that were the subject of meetings with business firms and trade associations were more or less likely to be changed relative to environmental rules that were the subject of meetings with environmental groups. One can also examine whether economically significant rules seem to be changed more often relative to non-economically significant rules, whether proposed rules are changed more relative to final rules, and whether certain agencies' rules are more often changed than other agencies' rules. Finally, the written materials maintained by OIRA allow a determination of whether rules that were the subject of meetings were changed more or less often if written information was submitted by outside parties.

In short, the quantitative data examined here both provide several sources of interesting descriptive information about rulemaking review by the White House. This data also allows statistical testing for associations between such things as the type of rule reviewed and the likelihood that a rule will be changed, the type of interests attending an OIRA meeting and the likelihood that a rule will be changed, the agency developing the rule and the likelihood that a rule will be changed, and the agency developing a rule and the likelihood that there will be an OIRA meeting.

Because data never quite speak for themselves, however, the analysis here is informed by qualitative, as well as the previously described quantitative, sources. Specifically, the interpretation of some of the findings below is informed by conversations with OIRA personnel, including the Branch Chiefs of each of the divisions of OIRA, an Acting Administrator, and especially the Administrator of OIRA during most of the Clinton era, Sally Katzen. These sources include individuals most knowledgeable about OIRA rulemaking review generally and OIRA contacts with persons outside of government in particular. While these conversations are all treated as confidential (some were, others were not), and thus none of their contents revealed, they provided valuable background information about how OIRA is organized and how the rulemaking review process works, and they furthermore influence the interpretation of some of the findings below. The following Parts present the findings the data yield. 
C. General Trends: $1981-2000$

For the twenty-year period from 1981 to 2000, the White House reviewed a grand total of 34,386 rules (proposed and final combined). Of these, 1,693 were economically major or economically significant, and 32,693 were otherwise major or significant. Among economically major/significant rules - as defined by the Reagan and Clinton orders-rules from the EPA, the Department of Health and Human Services ("HHS"), the DOT, and the Department of Agriculture ("USDA") made up the lion's share, with a combined total of 1,155 , or 68 percent of all economically major/significant rules. The next tier, by quantity of rules submitted, was occupied by the Department of Commerce ("DOC"), the Department of the Interior ("DOI"), and the Department of Labor ("DOL"). As a general rule, agencies submitting the most economically major/significant rules also submitted the most otherwise significant rules, with a few exceptions, such as the Department of Veterans Affairs ("VA"), which submitted over 1,000 otherwise significant rules and only a few economically significant rules during this 20 -year period.

The distribution of rules reviewed was not constant during the period, however. Rather, the White House reviewed a declining number of rules, with a sharp decline immediately following the issuance of Executive Order 12866, due to that order's focus on economically significant rules, as discussed below. Figure 1 shows the number of rules reviewed by OIRA for the past two decades, beginning with the first Reagan administration through the end of the second Clinton administration: 
Figure 1: Number of Rules Reviewed by OIRA, 1981-2000

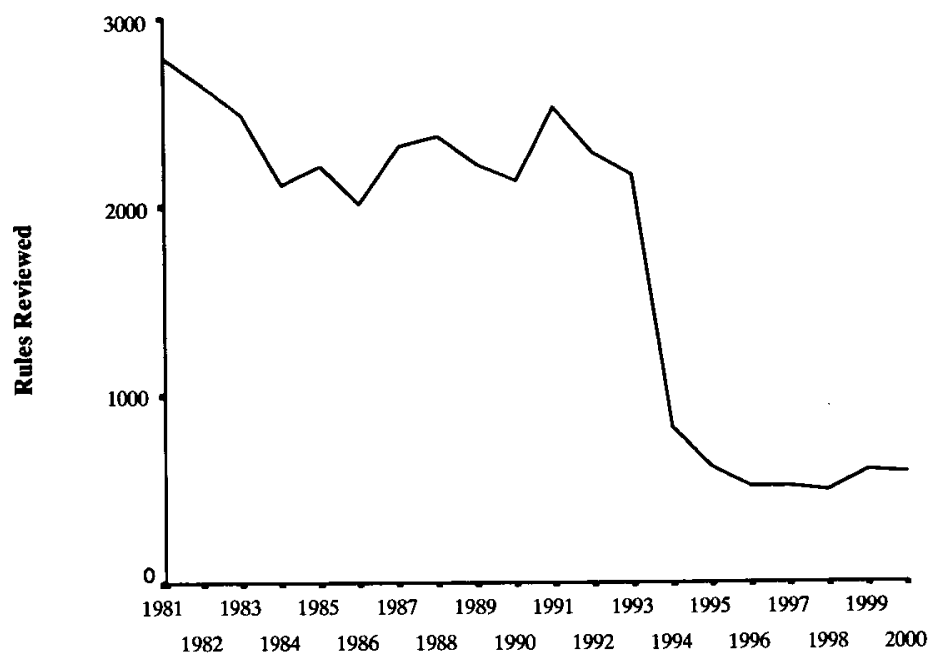

As Figure 1 shows, by 2000, OIRA reviewed an annual total of 583 rules (93 of which were economically significant), as compared with 2,286 (121 of which were economically major) in 1992 and 2,790 (60 of which were economically major) in 1981. Assuming the OIRA staff consists of 30 persons, and assuming (unrealistically) that only one member of OIRA's staff works on any given rule, this means a single staff person would review on average 19 rules for 2000 (including 3 economically major rules), in contrast to 76 rules for 1992 (including 4 economically major rules) and 93 rules (including 2 economically major rules) for 1981 . Assuming that OIRA's staff works roughly 60,000 person hours per year on all aspects of rulemaking review ( 30 people $\times 40$ hours $\times 50$ weeks $=60,000$ ), each of the submitted rules for 2000 would have received on average 103 person hours of attention, while the rules submitted for 1992 would have received on average 26 hours and those for 1981 would have received 22 hours of review attention. ${ }^{6}$

Figures 2 and 3 show the absolute numbers and percentages, respectively, of the rules changed and unchanged during the review process for the same twenty-year period:

69 These estimates, while reasonably illustrative, are high given that OIRA designates significant human resources to Paperwork Reduction Act review as well. 
Figure 2: Number of Rules Changed and Unchanged during Review Process, 1981-2000

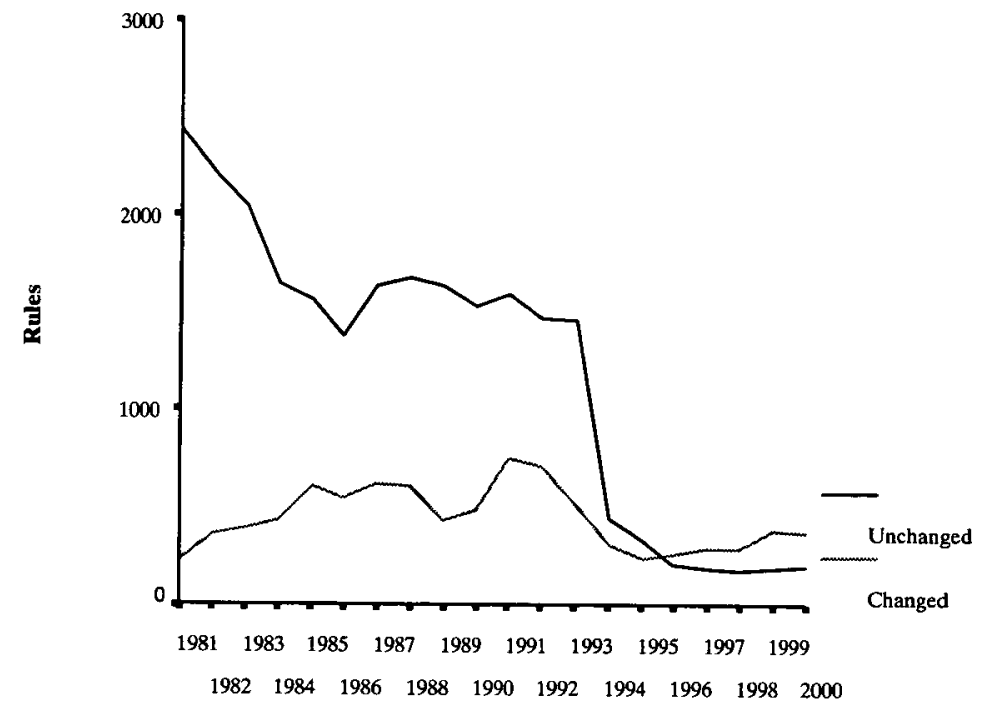

Figure 3: Percentage of Rules Changed and Unchanged during Review Process, 1981-2000

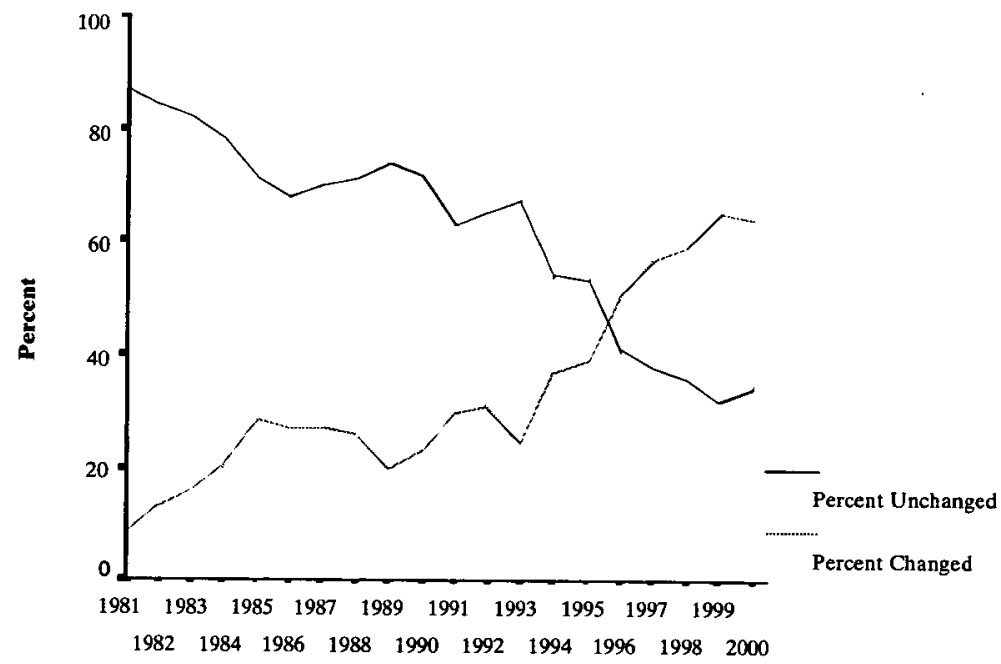


As these figures show, beginning in 1995, and every year since, the White House changed more rules than it approved without a change. For most of those years, it did so at an increasing rate. Dividing the two decades from 1981 to 2000 in two at the time of the Clinton order (1993), the ratio of rules not changed and changed from 1981 to October 1993 is $3: 1$, whereas the same ratio for the period from October 1993 through 2000 is closer to 1:1. The next Parts focus on the Clinton era, further contrasting that period with the ReaganBush era.

\section{Rulemaking Review During the Clinton Administration}

OIRA review changed following President Clinton's Executive Order 12866 in at least two important ways. First, as Figure 1 shows, a much smaller number of rules received OIRA scrutiny during the Clinton administration than during the Bush administration. Roughly, the Clinton OIRA scrutinized only about one-quarter the number of rules examined by the Bush White House. In 1989, for example, the number of rules submitted to OIRA for review totaled 2,217, a number that fell almost steadily from 1993 until 2000, when 583 rules were submitted to OIRA for review.

The reason for this change is in part easy to understand and in part puzzling. On the one hand, as explained above, whereas Executive Order 12291 required a Regulatory Impact Analysis for all "major" rules (as defined by that order), whether or not they qualified as "major" because of their projected annual impact on the economy of $\$ 100$ million or more, Clinton's Executive Order 12866 required an analogous extensive cost-benefit analysis mostly for "economically significant" rules-again, significant rules that qualify as "significant" (as defined by that order) usually because of their projected annual impact on the economy of $\$ 100$ million or more. ${ }^{70}$ Rules meeting Ex-

70 The RISC data's category for "change" is overinclusive, however. That is, those data do not distinguish between substantive changes in a rule, on the one hand, and minor stylistic or technical changes, on the other. Instead, all revisions to a rule, big or inconsequential, are counted as a "change" for the purposes of the RISC log. This means that, for the purposes of the present analysis, some rules are counted as changed rules that were not changed in a meaningful way during the review process. Unfortunately, it is not possible to know how "watered down" (by merely technically changed rules) the dependent variable here is; it is not possible to know, in other words, how many rules labeled as "changed" by the RISC were in fact not meaningfully altered during the review process. What is clear is that all rules that were substantively changed during the process are properly labeled as "changed," and furthermore that rules labeled as "unchanged" were not changed at all during the review process. Still, the analysis in the text that follows must be interpreted with some caution. It is perfectly possible that the same results would be reached by a more fine-tuned classification scheme. It is also possible, however, that the overinclusiveness of the category "change" masks some correlation between the dependent variable and one or more independent variables that is really there.

While the RISC and OMB do not have data distinguishing among different types of 
ecutive Order 12866's definition of "significant" for other reasons did not require an extensive cost-benefit analysis, but rather only a short summary of potential costs and potential benefits. In short, whereas the Reagan order required extensive analysis of all rules meeting the definition of "major," the Clinton order focused more specifically on "significant" rules that met the $\$ 100$ million threshold.

Having said this, however, the Clinton order too required some amount of OIRA review of non-economically significant rules, and indeed the category of "non-economically significant" rules is recorded in the GSA/RISC data throughout the Clinton era. Even though the Clinton OIRA focused on rules meeting the $\$ 100$ million threshold by requiring more extensive review of economically significant rules, it remains unclear why fewer total rules were submitted to OIRA for some kind of review or another. In any event, the number of economically significant rules submitted for review during the Clinton administration is comparable to (and slightly higher than) the number of "economically major" rules during the Reagan-Bush era, as Figure 4 shows. For whatever reason, the Clinton OIRA seems to have reviewed, or recorded the review of, many fewer noneconomically significant and/or non-significant rules.

changes to a rule, in principle it would be possible to develop such a classification scheme by going through rulemaking dockets and making judgments about the scope of changes made. Obviously, such a scheme would not be comprehensive, as one would have to sample rulemaking dockets, each one of which can be inches if not feet thick. Such a methodology is beyond the scope of the present, global study.

The General Accounting Office ("GAO"), however, is currently conducting a study of the rulemaking dockets of approximately one hundred rules reviewed during the first year of the George W. Bush administration. The GAO's findings are forthcoming in a study to be published later this year, undertaken at the request of Senators Richard Durbin and Joseph Lieberman. Those findings will be of great interest. No doubt the GAO's study at least in part reflects the general tension between the GAO and the White House concerning the openness or lack thereof of the White House during the present Bush administration. See, for example, Richard Simon, Push For Cheney Energy Data Ends, LA Times A12 (Feb 8, 2003); Neely Tucker, Suit Versus Cheney Is Dismissed; Judge Gives Administration Broad Victory on Oversight, Wash Post A1 (Dec 10, 2002); Neely Tucker, Cheney-GAO Showdown Goes to Court; Both Sides Warn that Their Key Powers and Principles Are at Stake, Wash Post A5 (Sept 28, 2002). 


\section{Figure 4: Number of Rules with Expected Annual Impact on the Economy of $\$ 100$ Million or More, 1981-2000}

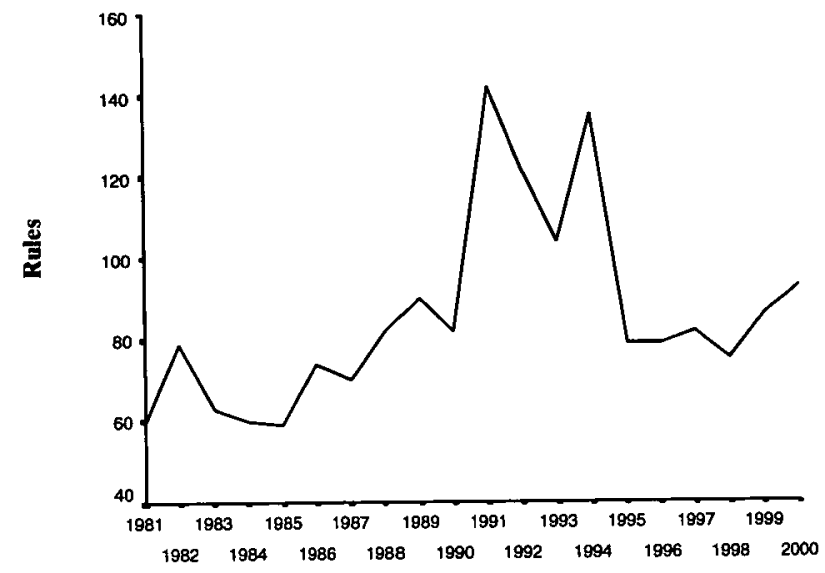

The number of economically significant rules submitted during the Clinton administration ran from 104 in 1993 to 75 in 1998, peaking at 136 in 1994. During the Reagan-Bush era, agencies submitted a high of 142 economically major rules in 1991, and a low of 59 economically major rules in 1985 .

Another interesting point of contrast between the Reagan-Bush and Clinton eras concerns the percentage of reviewed rules changed during the review process, as shown in Figure 3 . While the Clinton OIRA focused on fewer rules, it required a change in a much higher percentage of the rules it reviewed. Of course, it is possible that the absolute number of rules changed following OIRA review remained constant or even fell during the Clinton administration, but because the Clinton White House reviewed far fewer rules, the percentage of those changed increased-a mathematical side-effect. As Figure 2 above shows, the absolute number of rules changed during the Clinton review process is indeed slightly smaller than that changed in the Bush era. On the other hand, one might have expected the number of rules changed by the Clinton OIRA to be much lower relative to the Bush era. Apart from the number of total rules reviewed under Clinton as compared to Bush, not all else is equal between a Democratic and a Republican White House. Rather, conventional wisdom might hold that a Democratic administration should be much more welcoming to regulation - to agency rulemaking - than a Republican administration. Certainly, the Reagan-Bush era was marked by explicit skepticism toward regulation. In this light, then, it is interesting that the 
percentage of rules changed during the Clinton years increases so dramatically.

There are several possible explanations. First, holding the size of OIRA's staff (and/or other White House reviewers) during the Reagan-Bush era constant, and assuming that each reviewer identifies problems requiring a change in approximately the same number of rules each year, it is to be expected that a smaller number of rules submitted for review would yield a larger percentage of changed rules. Second, holding the size of OIRA's staff and its number of person-hours devoted to rule review constant, one might expect that, with fewer rules to look at, reviewers analyzing fewer rules would be more likely to identify problems in rules requiring a change. For that reason too, the percentage of rules changed would increase. On the other hand, perhaps the explanation is not so mechanical, or at least not entirely so. After all, OIRA staffers are not rewarded for the number of problems they identify in rules, nor are they required to fill any "problem quota" for the rules they review.

But there are other possible explanations as well. If a president puts greater emphasis on rulemaking review in order to advance his own regulatory policies and priorities, then again one would expect a corresponding higher percentage of rule changes. Making the most use of the OIRA review process, in other words, would likely result in an increased number of rule changes. In this light, the higher percentage of changes during the Clinton era likely suggests that the Clinton White House used the OIRA review process the most effectively or actively. In contrast to the Reagan-Bush era, the Clinton White House may have required changes in rules under review not with a deregulatory aim, but rather with a regulatory aim-that is, to get a rule "right" rather than to narrow the rule's reach. At any rate, this interpretation is consistent with an increasing percentage of rule changes during the 1993-2000 period: Over the course of the Clinton administration, the White House more and more often utilized the review process to shape agency rulemaking. It is also supported by a similar pattern found among rules subject to OIRA meetings with private parties concerning rules under review, as explained below.

E. OIRA Meetings with Persons Outside of Government: 1993-2000

The OIRA meetings log required by Executive Order 12866 provides a picture of what kinds of agency rules are typically the subject of meetings, as well as of the interests represented at such meetings. In addition, because the OIRA meetings log usually identifies the rule that is the subject of a meeting, and because the RISC log contains information about the fate of particular rules, it is possible to examine 
whether different kinds of rules-rules from different agencies, rules of different types of significance, and rules whose meetings were prompted and attended by different types of interest groups, for example-seem more or less likely to be changed relative to other kinds of rules.

Accordingly, using the information contained in the meetings log, the analysis here first classifies rules that were the subject of meetings in three ways: according to the agency from which a rule initiates, the stage of the rule (proposed or final-two exclusive categories), and its type of significance (economically significant or otherwise significant-two different exclusive categories). The analysis further divides meetings into four different (and exclusive) categories according to the types of interests represented at one or more meetings where a given rule was discussed. Those categories include "narrow-interest" meetings, "broad-based interest" meetings, "pluralistic" meetings, and "inter-governmental" meetings. "Narrow-interest" meetings are defined as those attended by business firms and trade associations." "Broad-based" interest meetings are defined as those attended by environmental groups, consumer groups, and public advocacy groups. "Pluralistic" meetings are meetings attended by at least one representative from both of the above. Instances where a rule was the subject of more than one meeting - for while every meeting corresponds to a particular rule, some rules were the subject of more than one meeting-and where OIRA met with narrow interests on one occasion and broad-based interests on another concerning the same rule, are coded as "pluralistic meetings." For the purposes of this analysis, which explores whether the type of interests meeting with OIRA is correlated with a higher likelihood that a rule will be changed, multiple meetings about a single given rule are lumped together as one "meeting." Thus, narrow-interest meetings constitute instances where OIRA met only with narrow-interest groups about a given rule, while broad-based meetings cover instances where OIRA met only with broad-based groups about a given rule. "Inter-governmental" meetings are those whose attendees represented only local, state, or regional governmental bodies or associations.

The analysis here also codes for the number of actual meetings that were held about a given rule in order to examine whether this number is correlated with the likelihood of a change in that rule. OIRA meetings are further categorized according to whether any outside parties supplied written materials to OIRA staff, whether the

71 See Steven P. Croley, Theories of Regulation: Incorporating the Administrative Process, 98 Colum L Rev 1, 93-94 n 272 (1998) (distinguishing broad-based and narrow interest groups and explaining similar distinctions on which political scientists have long relied). 
agency whose rule was the subject of a meeting attended the meeting, whether the White House was represented by someone other than the Administrator of OIRA, and last but not least, whether the rule subject to a meeting was changed during the OIRA review process, treating whether the rule was changed as the dependent variable. ${ }^{72}$ These variables were coded in a manner summarized below in the Appendix to this Article.

The analysis here considered all entries into the OIRA meetings $\log$ from January 1, 1993 through November 8, 2000. The total number of logged meetings for the period is 350 . Of those, 84 were excluded from the analysis because the rule that was the subject of a given meeting was not identifiable (usually because its description in the meetings log was too cryptic), or because the meeting concerned a rule with a statutory deadline, in which case the RISC log does not indicate whether the rule was changed or approved without a change, or finally because the meeting was attended only by persons working for the federal government, in which case it is not clear why the meeting was included in the OIRA $\log$, but several were. That leaves 266 $(350-84=266)$ meetings with persons outside government concerning identifiable rules for which the RISC log indicates whether the meetings were changed or not changed during the OIRA review process. Of those 266 meetings, 113 concerned rules that were the subject of at least one other meeting. In other words, those 266 meetings concerned only 153 distinct rules $(266-113=153)$.

One immediate observation concerning OIRA meetings is how uncommon such meetings are relative to the total number of rules submitted to the White House. For the period from January 1, 1994 through December 31, 2000, OIRA reviewed 3,994 total rules (and 711 economically significant rules), whereas it conducted only about 350 meetings. Dividing the total number of rules roughly in two (because, again, OIRA reviews a rule at both its proposed and final stages, so that 3,994 rule reviews covers only about 2,000 distinct rules), and even assuming (counterfactually) that all of the 350 meetings concerned different rules, the analysis shows that only about 18 percent of rules submitted for review became the subject of an OIRA meeting. By that measure, one might conclude that OIRA meetings constitute an unimportant part of the White House review process, as indeed they may.

On the other hand, not all reviewed rules are equal, and so the simple percentage of rules that become the subject of one or more

72 That is, a change in a rule is modeled as the dependent variable, while the other characteristics of OIRA meetings mentioned above are treated as independent variables. Strictly speaking, however, the statistics presented in the text that follows test for correlations without needing to specify a dependent variable. 
meetings may not be very meaningful. After all, OIRA meetings dealt with many of the most important rulemakings - measured by political controversy, policy significance, or sheer scale-undertaken in recent years. For example, OIRA held several meetings concerning the EPA's ozone and particulate matter rules, and the EPA's rule concerning diesel fuel sulphur requirements. Similarly, the USDA's rule barring roads through millions of acres of National Forests was the subject of several OIRA meetings, as was OSHA's ergonomics rule. Such rules are among the most important promulgated by these agencies over the past several years, and they therefore constitute an interesting (though not random) set of rules for study.

Apart from the simple number of meetings contained in the OIRA $\log$, several findings concerning the type of rules in question and who attended the meetings are also somewhat surprising. First, non-economically significant rules were more often the subject of OIRA meetings (58 percent of meetings) than were economically significant rules-a surprising finding to the extent one would expect rules that have the farthest-reaching economic implications would most tend to generate the kind of political interest or opposition that would lead a party to request a meeting with OIRA. On the other hand, economically significant rules are disproportionately represented among rules that are the subject of OIRA meetings, constituting 42 percent of rules subject to a meeting in contrast to just over 15 percent of the total rules submitted to the White House for review during the same seven-year period. Second, outside parties met with the White House concerning proposed rules about as often (48 percent of meetings) as they did concerning final rules ( 52 percent), a fact surprising to the extent that parties interested in a rule might be expected to exert their persuasive efforts before the issuing agency, and only then come to the White House after having been unsuccessful at persuading the agency, once the submitted rule took its final form.

Less surprisingly, one or more representatives from the agency submitting the rule routinely attended ( 86 percent of the time) an OIRA meeting regarding that agency's rule, almost certainly to explain the rule to the private party who sought it or to defend the rule against those parties' criticisms, or both. Roughly one quarter (26 percent) of the time, representatives from the White House besides OIRA personnel attended meetings. Concerning written materials, parties attending an OIRA meeting usually provided (more than 57 percent of the time) OIRA personnel with written materials. Finally, of the 153 distinct-rule meetings counted for the purposes of this analysis, 28 percent (42) of them concerned rules that were also the subject of at least one other OIRA meeting (and therefore are not 
counted separately here) and 14 percent (21) were the subject of more than one other meeting, sometimes of a half-dozen meetings or more (and again therefore are not counted more than once here).

These results are summarized in Table 1:

Table 1: Features of OIRA Meetings and Rules the Subject of OIRA Meetings

\begin{tabular}{|l||l|}
\hline \multicolumn{1}{|c||}{ Rule Category } & \multicolumn{1}{c|}{ Percentage in Each Category } \\
\hline \hline Stage of Rule & $52 \%$ Final; 48\% Proposed \\
\hline Significance of Rule & $\begin{array}{l}42 \% \text { Economically Significant; 58\% Otherwise } \\
\text { Significant }\end{array}$ \\
\hline $\begin{array}{l}\text { Written Materials } \\
\text { Submitted to OIRA }\end{array}$ & $57 \%$ Yes; 27\% No; 16\% Unknown \\
\hline $\begin{array}{l}\text { Agency Attended } \\
\text { Meeting }\end{array}$ & $86 \%$ Yes; $14 \%$ No \\
\hline $\begin{array}{l}\text { White House (Besides } \\
\text { OIRA) Attended } \\
\text { Meeting }\end{array}$ & $26 \%$ Yes; 74\% No \\
\hline $\begin{array}{l}\text { Number of Meetings } \\
\text { about a Given Rule }\end{array}$ & $1 \mathrm{mtg}: 73 \%(111) ; 2$ mtgs: $14 \%(21) ;>2 \mathrm{mtgs:} 14 \%(21)$ \\
\hline
\end{tabular}

One finding not summarized in Table 1 also warrants careful consideration: A dwindling number of rules that were the subject of OIRA meetings were left unchanged during the review process in the later years of the Clinton administration. In fact, for all of 1999 only a single rule that was the subject of an OIRA meeting was left unchanged during OIRA review and, interestingly, during 2000 no rule the subject of a meeting was left unchanged.

Examination of the OIRA data further reveals that rulemaking agencies were not evenly represented at OIRA meetings, which is to say that not all agencies' rules were equally likely to be the subject of a meeting. Of course, some agencies are more important than others, and certainly some are far busier than others, so it is to be expected that some agencies' rules will generate more interest than others. Yet, the breakdown of agency rules subject to a meeting is not proportionate to the agencies' relative shares of the total number of rules submitted to OIRA for review. Figure 5 illustrates the share of OIRA meetings that were the subject of rules from the EPA, DOL, DOT, HHS, and USDA - the only agencies whose rules were the subject of at least 5 percent of all OIRA meetings. All other agencies that sub- 
mitted one or more rules to OIRA during the 1993-2000 period-of which there were 41 - are grouped together as "Other."

\section{Figure 5: Share of OIRA Meetings with Persons Outside Government by Agency Originating Rule}

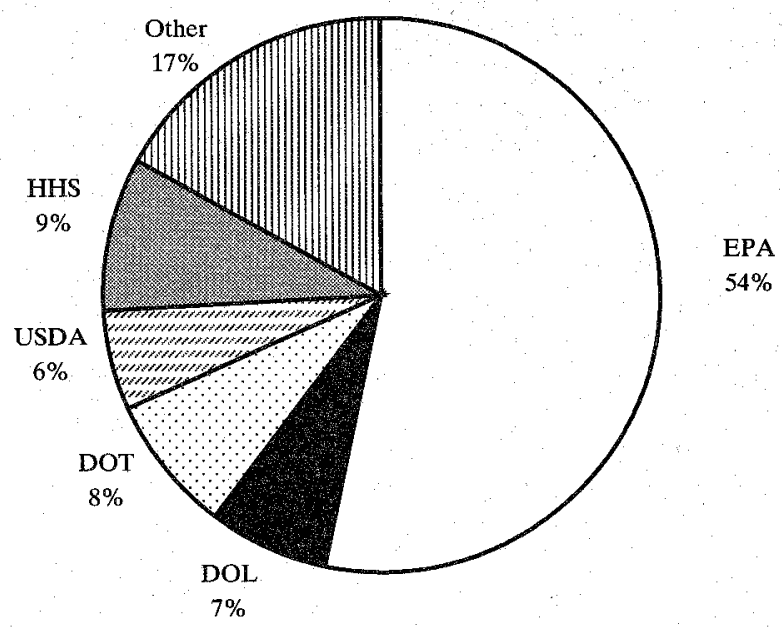

As Figure 5 shows, EPA rules were the subject of most OIRA meetings, 54 percent. For purposes of comparison, of all rules submitted for review during the 1993-2000 period, those coming from the EPA constituted only 10 percent of the total. Of all economically significant rules submitted for the same period, EPA rules constituted 23 percent. EPA rules, then, are vastly overrepresented among rules the subject of an OIRA meeting. ${ }^{73}$ Rules from HHS, DOT, DOL, and USDA comprised smaller and roughly equal percentages of the rules the subject of OIRA meetings $-9,8,7$, and 6 percent, respectively. Rules coming from all other agencies combined made up the remaining 17 percent.

As for who met with OIRA concerning rules under or pending review, Figure 6 illustrates the types of private interests that were represented at the OIRA meetings: 
Figure 6: Share of OIRA Meetings with Persons Outside Government by Interest-Group Type

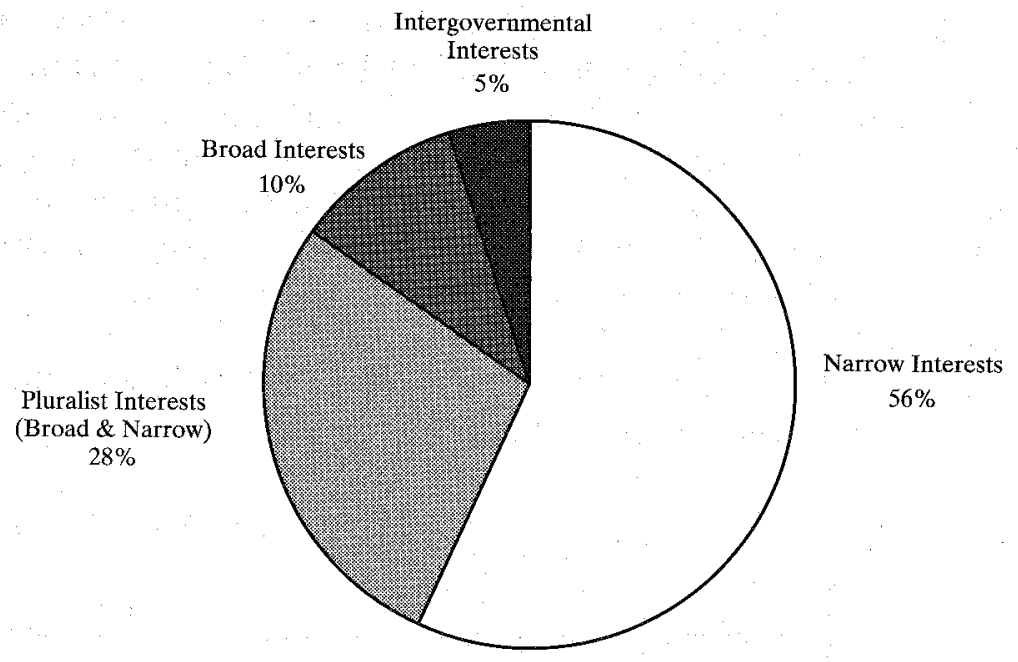

As Figure 6 shows, just over half (56 percent) of the rules that were the subject of OIRA meetings generated meetings attended solely by persons representing narrow interests, while over a quarter ( 28 percent) generated meetings attended by persons representing both narrow and broad-based interests, with solely broad-based interest meetings and inter-governmental meetings comprising the rest10 percent and 5 percent, respectively.

These descriptive findings are interesting in their own right, shedding some light on questions about who meets with OIRA and concerning what kinds of rules. As anticipated above, however, the primary purpose of coding the OIRA meetings log data is to facilitate inferential statistical analysis concerning the relationship between the type of rule subject to a meeting or the type of interests present at meetings, on the one hand, and the likelihood that a rule subject to a meeting will be changed, on the other hand. OIRA's ultimate treatment of a reviewed rule - to approve the rule without changes or to require one or more changes in the submitted rule - can be taken as the dependent variable for inferential analysis. Accordingly, the coding scheme employed here allows for cross-tabulations to identify associations between the type of rule and the type of interests represented at a meeting, and the dependent variable "change." Were correlations to be found among many of the examined variables, one 
could use logistic regression to explore the relative weight of those variables. $^{74}$

Interestingly, however, chi-square analysis of all of the coded meeting variables yields no statistically significant correlations between rule stage, type of rule significance, and written submissions, on the one hand, and the frequency with which submitted rules were changed, on the other. That is to say, for the purposes of predicting a rule change, neither a rule's stage, nor its economic significance, nor outside parties' attempts to persuade OIRA staff concerning the merits of a rule through written submissions matter, as Table 2 shows:

\section{Table 2: Cross-Tabulations of Rule Change over Rule Stage, Rule Significance, and Written Submission}

\begin{tabular}{|c|c|c|c|c|}
\hline & \multicolumn{2}{|c|}{$\begin{array}{l}\text { Rules Approved } \\
\text { with No Change }\end{array}$} & Rules Changed & $\begin{array}{l}\text { Fisher's Exact } \\
\text { Test of } \\
\text { Correlation } \\
\end{array}$ \\
\hline Proposed Rules & $\begin{array}{l}\text { Actual: } \\
\text { Expected: }\end{array}$ & $\begin{array}{l}9 \\
9.7\end{array}$ & $\begin{array}{ll}\text { Actual: } & 65 \\
\text { Expected: } & 64.3\end{array}$ & \\
\hline Final Rules & $\begin{array}{l}\text { Actual: } \\
\text { Expected: }\end{array}$ & $\begin{array}{l}11 \\
10.3\end{array}$ & $\begin{array}{ll}\text { Actual: } & 68 \\
\text { Expected: } & 68.7\end{array}$ & 0.813 \\
\hline $\begin{array}{l}\text { Not Economi- } \\
\text { cally Significant }\end{array}$ & $\begin{array}{l}\text { Actual: } \\
\text { Expected: }\end{array}$ & $\begin{array}{l}12 \\
11.6\end{array}$ & $\begin{array}{ll}\text { Actual: } & 77 \\
\text { Expected: } & 77.4\end{array}$ & \\
\hline $\begin{array}{l}\text { Economically } \\
\text { Significant }\end{array}$ & $\begin{array}{l}\text { Actual: } \\
\text { Expected: }\end{array}$ & $\begin{array}{l}8 \\
8.4\end{array}$ & $\begin{array}{ll}\text { Actual: } & 56 \\
\text { Expected: } & 55.6\end{array}$ & 1.000 \\
\hline $\begin{array}{l}\text { No Written } \\
\text { Submission }\end{array}$ & $\begin{array}{l}\text { Actual: } \\
\text { Expected: }\end{array}$ & $\begin{array}{l}5 \\
6.4\end{array}$ & $\begin{array}{ll}\text { Actual: } & 36 \\
\text { Expected: } & 34.6\end{array}$ & \\
\hline $\begin{array}{l}\text { Written } \\
\text { Submission }\end{array}$ & $\begin{array}{l}\text { Actual: } \\
\text { Expected: }\end{array}$ & $\begin{array}{l}15 \\
13.6\end{array}$ & $\begin{array}{ll}\text { Actual: } & 72 \\
\text { Expected: } & 73.4\end{array}$ & 0.604 \\
\hline
\end{tabular}

¥ The Fisher's Exact Test is a measure of whether the difference between the actual number of cases in a given cell of the table and the expected number of cases in that cell is statistically significant. The expected number of cases is calculated simply by assuming that the null hypothesis - there is no correlation between examined cases-is correct. The farther the actual number of cases deviates from the expected number, the more the null hypothesis is thrown into question. The statistic in the last column of the above table and the tables that follow in the text below essentially reports the probability of getting the actual cell count if the null hypothesis were correct. The null hypothesis is rejected, and a correlation considered statistically significant, if the Fisher's statistic is less than or equal to 0.10 .

Indeed, as these cross-tabulations show, the expected and actual counts of changed and unchanged rules over a rule's stage, signifi-

74 Because the cross-tabulations that follow yield few statistically significant correlations, logistic analysis of the data presented here is unlikely to illuminate more about OIRA meetings. To be comprehensive, however, logistic analysis was performed on the data, yielding results consistent with all of the findings reported here, as was expected given that logistic analysis here essentially tests for the same correlations. 
cance type, and written submissions are extremely close. Moreover, perhaps surprisingly, the types of interests present at an OIRA meeting are not associated with a greater or lesser likelihood that OIRA will require a change in the rule, as Table 3 shows.

\section{Table 3: Cross-Tabulations of Rule Change over Type of Interest Represented: Narrow, Broad-Based, Pluralistic, and Intergovernmental}

\begin{tabular}{|c|c|c|c|c|c|}
\hline & $\begin{array}{l}\text { Rules Apprc } \\
\text { with No Cha }\end{array}$ & $\begin{array}{l}\text { oved } \\
\text { ange }\end{array}$ & Rules Chan & ged & $\begin{array}{l}\text { Fisher's Exact } \\
\text { Test of } \\
\text { Correlation }\end{array}$ \\
\hline $\begin{array}{l}\text { Narrow Interest } \\
\text { Only }\end{array}$ & $\begin{array}{l}\text { Actual: } \\
\text { Expected: }\end{array}$ & $\begin{array}{l}13 \\
11.2\end{array}$ & $\begin{array}{l}\text { Actual: } \\
\text { Expected: }\end{array}$ & $\begin{array}{l}73 \\
74.8\end{array}$ & \\
\hline $\begin{array}{l}\text { All Other } \\
\text { Interests }\end{array}$ & $\begin{array}{l}\text { Actual: } \\
\text { Expected: }\end{array}$ & $\begin{array}{l}7 \\
8.8\end{array}$ & $\begin{array}{l}\text { Actual: } \\
\text { Expected: }\end{array}$ & $\begin{array}{l}60 \\
58.2\end{array}$ & 0.473 \\
\hline $\begin{array}{l}\text { Broad Based } \\
\text { Interests Only }\end{array}$ & \begin{tabular}{|l} 
Actual: \\
Expected:
\end{tabular} & $\begin{array}{l}0 \\
2.1\end{array}$ & $\begin{array}{l}\text { Actual: } \\
\text { Expected: }\end{array}$ & $\begin{array}{l}16 \\
13.9\end{array}$ & \\
\hline $\begin{array}{l}\text { All Other } \\
\text { Interests }\end{array}$ & $\begin{array}{l}\text { Actual: } \\
\text { Expected: }\end{array}$ & $\begin{array}{l}20 \\
17.9\end{array}$ & $\begin{array}{l}\text { Actual: } \\
\text { Expected: }\end{array}$ & $\begin{array}{l}117 \\
119.1\end{array}$ & 0.132 \\
\hline $\begin{array}{l}\text { Pluralistic } \\
\text { Interests Only }\end{array}$ & $\begin{array}{l}\text { Actual: } \\
\text { Expected: }\end{array}$ & $\begin{array}{l}4 \\
5.5\end{array}$ & $\begin{array}{l}\text { Actual: } \\
\text { Expected: }\end{array}$ & $\begin{array}{l}38 \\
36.5\end{array}$ & \\
\hline $\begin{array}{l}\text { All Other } \\
\text { Interests }\end{array}$ & $\begin{array}{l}\text { Actual: } \\
\text { Expected: }\end{array}$ & $\begin{array}{l}16 \\
14.5\end{array}$ & $\begin{array}{l}\text { Actual: } \\
\text { Expected: }\end{array}$ & $\begin{array}{l}95 \\
95.5\end{array}$ & 0.593 \\
\hline $\begin{array}{l}\text { Inter- } \\
\text { Governmental } \\
\text { Interests Only }\end{array}$ & $\begin{array}{l}\text { Actual: } \\
\text { Expected: }\end{array}$ & $\begin{array}{l}2 \\
1.0\end{array}$ & $\begin{array}{l}\text { Actual: } \\
\text { Expected: }\end{array}$ & $\begin{array}{l}6 \\
7.0\end{array}$ & \\
\hline $\begin{array}{l}\text { All Other } \\
\text { Interests }\end{array}$ & $\begin{array}{l}\text { Actual: } \\
\text { Expected: }\end{array}$ & $\begin{array}{l}18 \\
19.0\end{array}$ & $\begin{array}{l}\text { Actual: } \\
\text { Expected: }\end{array}$ & $\begin{array}{l}127 \\
126.0\end{array}$ & 0.281 \\
\hline
\end{tabular}

The fact that the White House met only with broad-based interests concerning some rule under review, or only with narrow interests, or both, has no apparent bearing on the likelihood that the White House would require a change in the rule. In fact, as Table 3 shows, the White House changed a disproportionately high number of rules that were the subject of meetings only with broad-based groups, though not to a statistically significant extent, a finding at odds with any simple picture of White House review according to which the White House delivers regulatory favors to economically powerful interest groups while ignoring broad-based interests. Nor does the fact that the White House heard only from state or local politicians or of- 
ficials, or federal politicians acting on their behalf have any apparent effect on the White House's treatment of a rule under review.

Of course, this result does not imply that all types of groups fared equally well before the White House. It is entirely possible, for example, that narrow interests routinely persuaded the White House to require changes in rules favorable to those interests, whereas broadbased interests never saw the changes they preferred but the White House made changes to the rules in which broad-based groups happened to be most interested. Similarly, it is possible that most pluralistic meetings produced changes favored by narrow interests and opposed by broad-based interests. The data showing roughly the same propensity on the part of the White House to require changes in rules no matter which type of interest groups met with OIRA staff are compatible with such possibilities.

Still, if the White House were particularly attentive to one type of interest group or another, one would expect this to show up in the data: Rules precipitating meetings with one type of group would have a higher/lower probability of changing as a result of those meetings. While the data do not demonstrate that the White House responded to all groups evenhandedly, they are consistent with that possibility, and they certainly do not show that some kinds of interests but not others benefit from White House review. For that matter, the interestgroup data are also consistent with the possibility that meetings themselves, with any type of interest group, have no apparent effect on the likelihood that the White House will require a change to a rule under review, although as explained below there is a strong correlation (which does not imply causation) between the existence of one or more meetings, on the one hand, and rule changes, on the other hand.

Surprisingly, White House attendance at a meeting is also not associated with a greater likelihood that a rule will be changed. For just over a quarter of all OIRA meetings, the White House was represented variously by one or more persons from the Council of Economic Advisors, the Council on Environmental Quality, the Office of Science and Technology Policy, the Office of the Vice President, or some other White House agency. At such meetings, the White House is thus essentially represented twice - by OIRA itself, whose Administrator is almost always present (sometimes joined by one or more OIRA staffers), and by some other member of the White House. To the extent OIRA meetings provide the White House with an occasion for monitoring agencies to ensure that agency rules conform to the President's regulatory priorities, and for correcting instances when they do not, OIRA meetings attended by representatives from a White House agency besides OIRA should be especially useful for that purpose. Consequently, one might expect that the White House's 
presence at a meeting-reflecting concern with a rule or political sensitivity to its underlying subject matter-would increase the likelihood that the rule under review would be changed. However, there is no correlation between White House representation at a meeting and the likelihood that the rule in question will be changed, as Table 4 shows:

\section{Table 4: Cross-Tabulations of Rule Change over White House Presence and Agency Pressure}

\begin{tabular}{|c|c|c|c|c|}
\hline & \multicolumn{2}{|c|}{$\begin{array}{l}\text { Rules Approved with } \\
\text { No Change }\end{array}$} & Rules Changed & $\begin{array}{l}\text { Fisher's } \\
\text { Exact } \\
\text { Test of } \\
\text { Correlation }\end{array}$ \\
\hline $\begin{array}{l}\text { No White } \\
\text { House Presence }\end{array}$ & $\begin{array}{l}\text { Actual: } \\
\text { Expected: }\end{array}$ & $\begin{array}{l}16 \\
14.8\end{array}$ & $\begin{array}{ll}\text { Actual: } & 97 \\
\text { Expected: } & 98.2\end{array}$ & \\
\hline $\begin{array}{l}\text { White House } \\
\text { Presence (Be- } \\
\text { sides OIRA) }\end{array}$ & $\begin{array}{l}\text { Actual: } \\
\text { Expected: }\end{array}$ & $\begin{array}{l}4 \\
5.2\end{array}$ & $\begin{array}{ll}\text { Actual: } & 36 \\
\text { Expected: } & 34.8\end{array}$ & 0.595 \\
\hline $\begin{array}{l}\text { No Agency } \\
\text { Attendance }\end{array}$ & $\begin{array}{l}\text { Actual: } \\
\text { Expected: }\end{array}$ & $\begin{array}{l}8 \\
2.7\end{array}$ & $\begin{array}{ll}\text { Actual: } & 13 \\
\text { Expected: } & 18.3\end{array}$ & \\
\hline $\begin{array}{l}\text { Agency } \\
\text { Attendance }\end{array}$ & $\begin{array}{l}\text { Actual: } \\
\text { Expected: }\end{array}$ & $\begin{array}{l}12 \\
17.3\end{array}$ & $\begin{array}{ll}\text { Actual: } & 120 \\
\text { Expected: } & 114.7\end{array}$ & 0.001 \\
\hline
\end{tabular}

Apparently, a representative from a White House agency sometimes appeared at OIRA meetings to demonstrate that the administration was concerned about a rule, or about a private party's criticism of a rule, or perhaps to defend a rule against criticisms. Whichever the case, White House representation at an OIRA meeting is no predictor of a change in the rule.

As Table 4 also shows agency representation is statistically significantly correlated with a rule change. Rules that were the subject of OIRA meetings attended by one or more representatives from the rule's originating agency were more likely to be changed. One conclusion consistent with this finding is that agency representatives are particularly bad at defending their rules before critics of the White House. A much better interpretation is that agencies send representatives to OIRA meetings only for rules that are especially controversial or complicated and thus most likely to be changed. As Table 5 shows, there are no significant correlations between the presence of the agency at a meeting, on the one hand, and the species of signifi- 
cance of the rule, the stage of the rule, or the type of interests represented at a meeting concerning the rule, on the other.

Table 5: Cross-Tabulations of Agency Presence over Economic Significance, Rule Stage, and Narrow Interest Representation

\begin{tabular}{|c|c|c|c|c|c|}
\hline & \multicolumn{2}{|c|}{$\begin{array}{l}\text { No Agency } \\
\text { Presence }\end{array}$} & \multicolumn{2}{|l|}{$\begin{array}{l}\text { Agency } \\
\text { Presence }\end{array}$} & $\begin{array}{l}\text { Fisher's Exact } \\
\text { Test of } \\
\text { Correlation }\end{array}$ \\
\hline $\begin{array}{l}\text { Not Economi- } \\
\text { cally Significant }\end{array}$ & $\begin{array}{l}\text { Actual: } \\
\text { Expected: }\end{array}$ & $\begin{array}{l}15 \\
12.2 \\
\end{array}$ & $\begin{array}{l}\text { Actual: } \\
\text { Expected: }\end{array}$ & $\begin{array}{l}74 \\
76.8 \\
\end{array}$ & \\
\hline $\begin{array}{l}\text { Economically } \\
\text { Significant }\end{array}$ & $\begin{array}{l}\text { Actual: } \\
\text { Expected: }\end{array}$ & $\begin{array}{l}6 \\
8.8\end{array}$ & $\begin{array}{l}\text { Actual: } \\
\text { Expected: }\end{array}$ & $\begin{array}{l}58 \\
55.2\end{array}$ & 0.236 \\
\hline Proposed Rules & $\begin{array}{l}\text { Actual: } \\
\text { Expected: }\end{array}$ & $\begin{array}{l}13 \\
10.2\end{array}$ & $\begin{array}{l}\text { Actual: } \\
\text { Expected: }\end{array}$ & $\begin{array}{l}61 \\
63.8\end{array}$ & \\
\hline Final Rules & $\begin{array}{l}\text { Actual: } \\
\text { Expected: }\end{array}$ & $\begin{array}{l}8 \\
10.8\end{array}$ & $\begin{array}{l}\text { Actual: } \\
\text { Expected: }\end{array}$ & $\begin{array}{l}71 \\
69.2 \\
\end{array}$ & 0.241 \\
\hline Other Interests & $\begin{array}{l}\text { Actual: } \\
\text { Expected: }\end{array}$ & $\begin{array}{l}8 \\
9.2 \\
\end{array}$ & $\begin{array}{l}\text { Actual: } \\
\text { Expected: }\end{array}$ & $\begin{array}{l}59 \\
57.8 \\
\end{array}$ & \\
\hline $\begin{array}{l}\text { Narrow } \\
\text { Interests Only }\end{array}$ & $\begin{array}{l}\text { Actual: } \\
\text { Expected: }\end{array}$ & $\begin{array}{l}13 \\
11.8\end{array}$ & $\begin{array}{l}\text { Actual: } \\
\text { Expected: }\end{array}$ & $\begin{array}{l}73 \\
74.2\end{array}$ & 0.641 \\
\hline
\end{tabular}

If it is true that agencies send representatives only to meetings concerning rules likely to be changed during the review process, then the findings summarized in Table 5 reinforce the findings summarized in Tables 2 and 3: The species of rule significance, a rule's stage, and the types of interests represented at a meeting are not correlated with a change in the rule, given that those same variables are not correlated with agency presence at a meeting. Indeed, as explained below, the only significant correlation associated with agency presence is the identity of the agency from which a rule originates.

The number of meetings concerning a given rule is also significantly correlated with a change in the rule. On the one hand, rules that were the subject of only two meetings are indistinguishable from rules that were the subject of a single meeting. On the other hand, rules that were the subject of more than two meetings were changed at a slightly disproportionately high rate that is statistically significant. These findings are shown in Table 6: 
Table 6: Cross-Tabulations of Rule Change over Two Meetings and Multiple Meetings

\begin{tabular}{|c|c|c|c|c|c|}
\hline & \multicolumn{2}{|c|}{ No Rule Change } & \multicolumn{2}{|c|}{ Rule Change } & $\begin{array}{l}\text { Fisher's Exact } \\
\text { Test of } \\
\text { Correlation }\end{array}$ \\
\hline One Meeting & $\begin{array}{l}\text { Actual: } \\
\text { Expected: }\end{array}$ & $\begin{array}{l}17 \\
17.3\end{array}$ & $\begin{array}{l}\text { Actual: } \\
\text { Expected: }\end{array}$ & $\begin{array}{l}115 \\
14.7\end{array}$ & \\
\hline Two Meetings & $\begin{array}{l}\text { Actual: } \\
\text { Expected: }\end{array}$ & $\begin{array}{l}3 \\
2.7\end{array}$ & $\begin{array}{l}\text { Actual: } \\
\text { Expected: }\end{array}$ & $\begin{array}{l}18 \\
18.3\end{array}$ & 0.740 \\
\hline $\begin{array}{l}\text { Two or Fewer } \\
\text { Meetings }\end{array}$ & $\begin{array}{l}\text { Actual: } \\
\text { Expected: }\end{array}$ & $\begin{array}{l}20 \\
17.3\end{array}$ & $\begin{array}{l}\text { Actual: } \\
\text { Expected: }\end{array}$ & $\begin{array}{l}112 \\
114.7\end{array}$ & \\
\hline $\begin{array}{l}\text { More Than } \\
\text { Two Meetings }\end{array}$ & $\begin{array}{l}\text { Actual: } \\
\text { Expected: }\end{array}$ & $\begin{array}{l}0 \\
2.7\end{array}$ & $\begin{array}{l}\text { Actual: } \\
\text { Expected: }\end{array}$ & $\begin{array}{l}21 \\
18.3\end{array}$ & 0.077 \\
\hline
\end{tabular}

More interestingly still, rules that were the subject of at least one OIRA meeting were far more likely to be changed relative to rules never the subject of an OIRA meeting: In the aggregate, rules that were the subject of an OIRA meeting during the 1993-2000 time period were changed 87 percent of the time, whereas rules that were not the subject of a meeting were for the same period changed 54 percent of the time. Clearly then, rules the subject of OIRA meetings are correlated with rules that are changed to a highly statistically significant extent.

Of course, this is not to say that meetings are causally linked to a change in a rule. More likely, both meetings and rule changes are the result-both indicators - of larger underlying political dynamics. This interpretation seems superior to the interpretation that finds a tight causal connection between OIRA meetings and rule changes for several reasons. First of all, any party can request a meeting with OIRA to discuss a rule under review, and although OIRA sometimes discourages such meetings on the ground that they are unnecessary to assist the office in understanding a rule's full implications, ultimately OIRA grants requests to anybody that persists. Because at least some substantial portion of OIRA meetings have as their primary purpose giving a rule's persistent critics a chance to air their concerns, it seems unlikely that OIRA staff are actually persuaded by what they hear at a meeting. Another reason to doubt that OIRA meetings lead directly to a change in the reviewed rule is that, again, there are so few meetings. Were there such a causal connection, or even a perceived one, in- 
terest groups would probably figure that out and seek meetings more often. Groups who believed that a final promulgated rule looked different because of objections they voiced to OIRA certainly would seek meetings regularly. Yet they do not.

More importantly, as mentioned above, the rules subject to OIRA meetings often included some of the most significant and controversial rules of the past several years. Such rules would tend to lead some party, or many, to request an OIRA meeting. Most likely, such rules also would be studied very closely by the White House, and agencies as a result would often have to change them. So again, an OIRA meeting is to be expected for the same set of rules that the White House scrutinizes most closely. In this light, both meetings and changes in the rule are effects of the underlying political dynamics of important rules. Change is thus positively correlated with a meeting, but is not necessarily the result of a meeting.

$\mathrm{Up}$ to this point, the analysis considers associations between rule changes and other variables, conceptualizing a change in a rule (or in one instance the presence of the agency) as the dependent variable. There are other possibilities as well. For one, meetings can be taken as the dependent variable with the agency originating a rule, for example, considered to be an independent variable: Do some agencies' rules seem especially likely to generate a meeting? The following Part takes up this question and others, focusing specifically on the EPA, the mother of rulemaking agencies.

\section{F. EPA Rules Specifically}

These days, much of agency rulemaking is EPA rulemaking. During the Clinton administration, the EPA issued more economically significant rules, 149 , than any other agency. Only two other agencies, HHS (121) and USDA (118), came close. During the Reagan-Bush era, EPA issued more major rules than any other agency except the USDA; EPA rules for the period 1981-1993 constituted 11 percent of all submitted rules and 16 percent of all economically major rules. Among the agencies during that time, the EPA probably had the most troubled relationship with the White House. Certainly, critics of White House oversight during the Reagan-Bush era regularly complained that the White House used the rulemaking review process to undermine environmental regulation.

75 For an especially thoughtful presentation of that thesis, see Claudia O'Brien, White House Review of Regulations under the Clean Air Act Amendments of 1990,8 J Envtl L \& Lit 51, 58-80 (1993) (noting instances where the Reagan-Bush White House acted as a "conduit for industry" to block or weaken a variety of EPA regulations, including: regulations mandating recycling, regulations banning the incineration of lead acid batteries, regulations placing pollution controls on power generators around the Grand Canyon, regulations requiring monitoring of 
By all appearances, EPA rules continued to be among the most significant and controversial during the Clinton era as well, notwithstanding that the Clinton White House was viewed by most to be quite friendly toward environmental regulation. From 1993-2000, OIRA meetings focused on EPA rules disproportionately even to their large share of either total rules or economically significant rules for the 1993-2000 period: As noted above, rules submitted to OIRA from the EPA constituted 10 percent of all rules submitted and 23 percent of all economically significant rules submitted, but 54 percent of the rules subject to OIRA meetings. Put differently, EPA rules were especially likely to generate OIRA meetings, to a statistically significant degree, as shown in the first two rows of Table 7.

acid rain producing sulfur dioxide emissions, and planned regulations of Nitrogen Oxides under the Clean Air Act). See also Margaret Carde, Comment, Can Bambi Ride Herd over Godzilla? The Role of Executive Oversight in EPA's Rulemaking for the Waste Isolation Pilot Plant, 36 Nat Res J 643, 666 (1996) (arguing that OMB, at times, used its authority to "review individual agency rulemaking in order to prevent contradictions between agencies" as a means to circumvent EPA decisions). 
Table 7: EPA versus Other Agencies: Cross-Tabulations of Originating Agency over Meetings, Agency Attendance, and Rule Change

\begin{tabular}{|c|c|c|c|}
\hline & Other Agency & EPA & $\begin{array}{l}\text { Fisher's Exact } \\
\text { Test of } \\
\text { Correlation } \\
\end{array}$ \\
\hline No Meeting & $\begin{array}{ll}\text { Actual: } & 3947 \\
\text { Expected: } & 3881.5\end{array}$ & $\begin{array}{ll}\text { Actual: } & 437 \\
\text { Expected: } & 502.7\end{array}$ & \\
\hline Meeting & $\begin{array}{ll}\text { Actual: } & 70 \\
\text { Expected: } & 135.5\end{array}$ & $\begin{array}{ll}\text { Actual: } & 83 \\
\text { Expected: } & 17.5\end{array}$ & 0.000 \\
\hline $\begin{array}{l}\text { No Agency } \\
\text { Attendance }\end{array}$ & $\begin{array}{ll}\text { Actual: } & 14 \\
\text { Expected: } & 9.6\end{array}$ & $\begin{array}{ll}\text { Actual: } & 7 \\
\text { Expected: } & 11.4\end{array}$ & \\
\hline $\begin{array}{l}\text { Agency } \\
\text { Attendance }\end{array}$ & $\begin{array}{ll}\text { Actual: } & 56 \\
\text { Expected: } & 60.4\end{array}$ & $\begin{array}{ll}\text { Actual: } & 15 \\
\text { Expected: } & 10.8\end{array}$ & 0.058 \\
\hline $\begin{array}{l}\text { No Rule Change } \\
\text { (OIRA rules) }\end{array}$ & $\begin{array}{ll}\text { Actual: } & 15 \\
\text { Expected: } & 9.2\end{array}$ & $\begin{array}{ll}\text { Actual: } & 76 \\
\text { Expected: } & 71.6\end{array}$ & \\
\hline $\begin{array}{l}\text { Rule Change } \\
\text { (OIRA rules) }\end{array}$ & $\begin{array}{ll}\text { Actual: } & 55 \\
\text { Expected: } & 60.8\end{array}$ & $\begin{array}{ll}\text { Actual: } & 78 \\
\text { Expected: } & 72.2\end{array}$ & 0.007 \\
\hline $\begin{array}{l}\text { No Rule Change } \\
\text { (Äll Rules, } \\
\text { 1993-2000) }\end{array}$ & $\begin{array}{ll}\text { Actual: } & 1946 \\
\text { Expected: } & 1856.8\end{array}$ & $\begin{array}{ll}\text { Actual: } & 151 \\
\text { Expected: } & 240.2\end{array}$ & \\
\hline $\begin{array}{l}\text { Rule Change } \\
\text { (All Rules, } \\
\text { 1993-2000) }\end{array}$ & $\begin{array}{ll}\text { Actual: } & 2073 \\
\text { Expected: } & 2162.2\end{array}$ & $\begin{array}{ll}\text { Actual: } & 369 \\
\text { Expected: } & 279.8\end{array}$ & 0.000 \\
\hline
\end{tabular}

In addition, there is a statistically significant correlation between agency representation at OIRA meetings, on the one hand, and the identity of the agency whose rule is the subject of a meeting, on the other hand, as Table 7 (third and fourth rows) shows. EPA staff are especially likely to attend meetings about their rules, relative to all other agencies. The EPA seems particularly apt to engage with private parties who initiate a meeting, or to explain or defend its rule to White House reviewers, or both.

And perhaps for good reason, for among rules that were the subject of OIRA meetings, EPA rules were statistically significantly more likely to be changed relative to all other agencies' rules (combined), as Table 7 (fifth and sixth rows) further shows. Thus, not only was the Clinton White House particularly active in reviewing agency rules generally - though in a more focused way than previous administra- 
tions because the Clinton White House concentrated on fewer rulesit also was especially active in influencing rules of the agency from which most significant rules originated. Put differently, the Clinton White House clearly appears to have used the review process to put its mark on environmental rulemaking, however friendly the Clinton administration was toward environmental regulation.

Whether the fact that a rule originates from the EPA is correlated with an increased likelihood of a change in the rule among all rules submitted for OIRA review, rather than simply among those rules that were the subject of an OIRA meeting, is also revealed by Table 7. As the bottom two rows of Table 7 show, among all rules submitted to OIRA during the Clinton administration, a disproportionately large number of EPA rules were changed, again to a (highly) statistically significant extent. Indeed, for the years 1998 through 2000, the EPA submitted to OIRA a total of 242 rules, 62 of which were economically significant. Of those 242 rules, only 26 were unchanged during the review process.

This last finding raises the question whether rules that are the subject of an OIRA meeting are positively correlated with changed rules simply by virtue of the fact that rules that are the subject of an OIRA meeting are mostly EPA rules. If EPA rules are especially likely to be changed during the White House review process, and if rules that are the subject of an OIRA meeting are especially likely to be EPA rules (though why this is true itself warrants explanation), does that explain why rules that are the subject of an OIRA meeting are especially likely to be changed? This question can be answered by comparing the frequency of change among non-EPA rules that were the subject of an OIRA meeting against the frequency of change among non-EPA rules that were not the subject of an OIRA meeting. If what drives the likelihood of change among rules subject to an OIRA meeting is simply the identity of the agency - in particular, the fact that the rules are disproportionately EPA rules - then one would expect that non-EPA rules that were the subject of OIRA meetings would be changed only about as often as non-EPA rules that were not the subject of OIRA meetings were changed. As it turns out, however, 79 percent of non-EPA rules that were the subject of OIRA meetings were changed, whereas only 52 percent of all non-EPA rules generally were changed during the review process, a large (and obviously statistically significant) difference. Thus, although EPA rules that are the subject of meetings are changed even more frequently than non-EPA rules that are the subject of meetings ( 94 percent of the time as opposed to 79 percent of the time), the fact that most rules that are the subject of OIRA meetings are EPA rules does not explain why most rules that are the subject of meetings are changed. 
Looking back over the entire period from 1981 to 2000 , Figure 7 summarizes the number of EPA rules submitted, and the number of EPA rules changed and unchanged.

Figure 7: Yearly Review of EPA Rules, 1981-2000

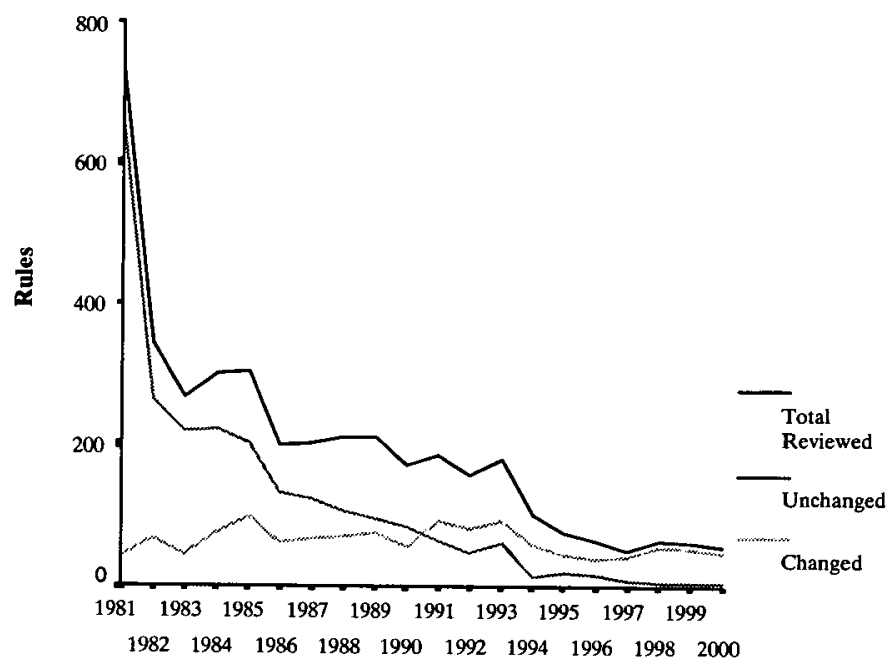

Figure 8 shows the number of economically major or economically significant rules submitted by the EPA for the same period. 
Figure 8: Economically Major/Significant EPA Rules

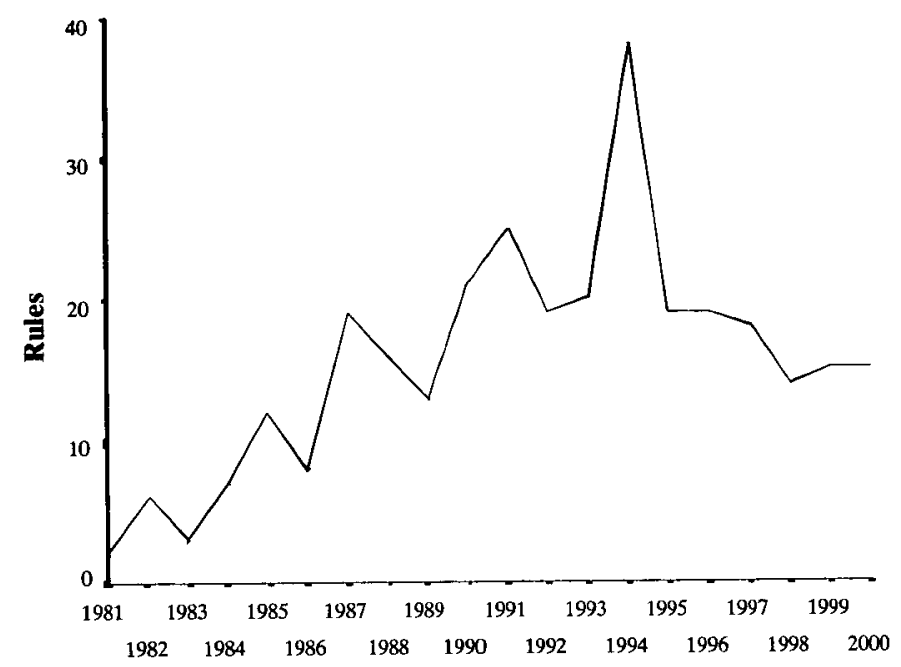

As Figure 7 shows, from as early as 1991, the White House required a change in more EPA rules than it left unchanged, an inversion that, as summarized above, ${ }^{76}$ took until 1995 when examining all agencies' rules in the aggregate. Further, as Figure 8 indicates, throughout the Clinton administration, the number of changed EPA rules exceeded those not changed by a greater amount each year, though the number of economically major or significant EPA rules was roughly constant from the late 1980 s to 2000 , even while the share of all major rules that were EPA rules increased from less than 10 percent in the early 1980 s to about 20 percent by the late 1990 s. EPA rules thus provide a more dramatic version of the general picture of rulemaking review during the Clinton administration, with fewer total rules reviewed, but with a comparable number of economically major or significant rules reviewed, and a much higher percentage of rules changed each year. Taken together, Figures 7 and 8 show that the Clinton administration engaged in more environmental regulation than did previous administrations and that the Clinton White House was more active in the development of environmental rules.

\section{G. Summary of Findings}

To summarize, the analysis here yields three sets of related findings. The first concerns the quantity of rules that the White House re- 
views, the resources the White House commits to rulemaking review, and the frequency with which rules submitted for review are subsequently changed. During the Reagan-Bush era, the White House reviewed over 2,000 proposed or final rules in a typical year, whereas the Clinton White House reviewed a mostly declining yearly total in the several hundreds. At the same time, the Clinton White House reviewed a much more comparable number of significant rules. In addition, from 1981 to 2000 the White House required a change in an increasing percentage of the rules it reviewed, a trend accelerated by the Clinton White House. Indeed, by all appearances the Clinton administration focused its rule review efforts on the smaller set of significant agency rules. Thus by 1995, two years after the issuance of Clinton's Executive Order 12866, the White House for the first time required a change in over 50 percent of all the rules it reviewed. Although it changed a somewhat smaller absolute number of rules relative to the Reagan-Bush era, again it appears the Clinton White House focused on fewer rules in a more concentrated way.

The second set of findings concerns the features and significance of OIRA meetings with outside parties concerning rules under White House review. Among the rules the Clinton OMB reviewed, only slightly over 10 percent were the subject of meetings logged by OIRA as required under Executive Order 12866, though that 10 percent represented some of the largest and most important rules of the Clinton era. OIRA met with outside parties concerning proposed rules and final rules roughly equally, and about non-economically significant rules slightly more often than about economically significant rules, although economically significant rules were overrepresented among rules the subject of an OIRA meeting. Almost half of the rules that led to an OIRA meeting led to more than one about the same rule. One or more representatives from the agency issuing a rule usually attended OIRA meetings, and the White House was represented by personnel from some office besides OIRA just over one-quarter of the time.

As for the types of interests represented at OIRA meetings, persons representing narrow interests were the only attendees for meetings concerning 56 percent of the rules that were the subject at meetings. Persons representing broad-based interests were the sole attendees for meetings concerning 10 percent of the rules subject to meetings. Twenty-eight percent of the rules spawned pluralistic meetings, attended by representatives from both narrowly interested and broadbased groups. Finally, representatives from local, state, or regional government organizations were the only attendees for 5 percent of the rules that were the subject of OIRA meetings. Parties attending 
OIRA meetings supplied written materials to OIRA staff concerning the rule in question roughly two-thirds of the time.

More than 85 percent of the rules that were the subject of OIRA meetings were changed during the OIRA review process, as compared with less than 60 percent of all rules reviewed during the same period, though it seems doubtful that meetings themselves were the direct cause of change, as opposed to reflections of underlying political dynamics that prompted a change. In any event, by 1999 and 2000 (combined) only a single rule that was the subject of a meeting was left unchanged during the review process. In addition, among the rules that were the subject of one or more OIRA meetings, rules that were the subject of more than two OIRA meetings were changed more often.

A change in a rule is not positively correlated to a statistically significant extent with the rule's stage or its species of significance, although again economically significant rules were more likely to become the subject of an OIRA meeting. Nor does it matter whether parties submitted written materials or, perhaps most surprisingly, even what kinds of interests were represented at OIRA meetings. Similarly, White House presence at OIRA meetings is not correlated with rule changes, and while agency presence is, that is almost certainly because agencies bother to send representatives only to meetings that focus on a rule that is controversial enough to be changed somehow during the course of the review process. Whatever agencies' motivations for deciding not to send representatives to a small minority of OIRA meetings, agency presence at a meeting is not positively correlated with a rule's stage or type of significance, or with the types of interests represented at the meetings, reinforcing the finding that those same three variables do not help to predict a change in the rule.

The third set of basic findings concerns EPA rules specifically. Not all agencies produce rules at the same pace, and not all are scrutinized by OIRA to the same extent. Among rulemaking agencies, the EPA is particularly important. The EPA promulgated more "economically significant" rules than any other agency during the Clinton administration, and the second most rules overall, and similarly, the second most "economically major" rules during the Reagan-Bush era. Even so, EPA rules were disproportionately highly represented among rules that were the subject of OIRA meetings, constituting over 50 percent of such rules, in contrast to the EPA's 10 percent share of all rules submitted to OIRA. In addition, EPA staff were most likely to attend meetings about their rules relative to staff from other agencies, probably because EPA rules were especially likely to be changed among the set of all rules subject to a meeting, even though non-EPA rules that were the subject of a meeting were also 
much more often changed relative to non-EPA rules that were not the subject of an OIRA meeting. Finally, among all rules submitted to OIRA for review, whether the subject of a meeting or not, a higher percentage of EPA rules were changed than were the rules of any other agency. EPA rules thus constitute a dramatic case of the general trend during the Clinton administration of fewer rules reviewed and a much higher percentage of them changed as a result of the OIRA review process.

\section{GOVERNMENT STRUCTURE AND REGULATORY THEORY REVISITED}

What is the importance of these findings? The above findings hardly settle the debate over the strong president, much less over alternative accounts of regulation more generally. On the other hand, they certainly inform that debate. They also shed light on which dimensions of the strong president debate are particularly important. The following Parts elaborate these points.

\section{A. In Defense of Activist White House Oversight}

A defender of the strong regulatory president can point to several of the above findings to help make the argument that White House review of rulemaking is, or can be, benign. First of all, the White House seems to concentrate on a manageable number of rules-given its institutional resources-totaling in the several hundreds. In addition to the OIRA staff, White House personnel from offices like the National Economic Council and the Council on Environmental Quality can and do commit some amount of resources to rulemaking review. Of course, while the White House reviews only significant rules, not all of those rules are so complicated as to require dozens of hours to understand. Moreover, OIRA's internal organization promotes specialization among reviewers, reducing the costs of review. Thus whatever the merits or demerits of White House review in principle, it seems safe to say that the White House has the institutional capacity to undertake meaningful review of agency rules. Critics of expanded White House review who argue such review can be at most only cursory seem unpersuasive.

Second, judging from the institutional resources that the White House commits to rule review, White House review appears to be at least partially technocratic and at any rate not ad hoc. Rules are reviewed in part as a check on agencies' cost-benefit analyses. And OIRA personnel who perform that review are consistent across changing presidential administrations and political parties, save one, the OIRA Administrator, who as an appointee serves as a bridge be- 
tween the White House's political offices and the professional OIRA staff. Of course, there is room for the White House to put values on regulatory costs or benefits in such a way as to advance its own political agenda, as critics of White House review (and of cost-benefit analysis more generally) often point out. But that task would not be as easy as critics suggest, for doing so in a crude political way would require corruption of OIRA's civil service. OIRA is probably capable of understanding and reviewing most agency rules on a meaningful level, but the Administrator alone is probably not. For that reason it seems unlikely that the OIRA Administrator serves simply as the White House's political tool who massages cost-benefit numbers to advance political ends.

Some of the OIRA meetings data provide further support for this conclusion. First, the fact that agencies typically attend OIRA meetings suggests that the White House kept good on Executive Order 12866's instruction for agency personnel to be informed of criticisms to their rules by outside groups, and further that there is at least some level of give-and-take between the White House and rulemaking agencies, as opposed to utterly hierarchical control over agency rules once they reach the White House. In addition, the Clinton order's required designation of Regulatory Policy Officers for rulemaking agencies helps to ensure that information about rules under review flows from OIRA to the agencies, not just the other way around. Furthermore, the fact that White House representation from offices other than OIRA does not predict a change in a rule suggests that the White House does not change rules whenever political considerations might dictate. Were the White House inclined and able to effect a rule change for crude political purposes, then one would expect some correlation between the presence of White House agencies at OIRA meetings and a change in the rules subject to those meetings. Put differently, the absence of such a correlation suggests that other White House offices, which in contrast to OIRA are typically filled with political appointees, do not strong-arm OIRA.

Third, with respect to OIRA meetings, defenders of White House oversight could point to the fact that OIRA will hold meetings to discuss rules under review with any outside party who requests a meeting. Furthermore, while narrowly focused interest groups make more requests than do other groups, still about 40 percent of OIRA meetings were attended either only by broad-based groups or by broadbased groups as well as narrow interest groups. More importantly still, and perhaps surprisingly, the type of interest group in attendance at an OIRA meeting does not predict whether the rule that is the subject of that meeting will be changed during the review process. If the White House used the review process to deliver regulatory benefits to 
powerful interests, one might have expected the presence of narrow interest groups to predict a change in rules. For that matter, if the White House used the review process to deliver regulatory benefits to interests it favored, such as environmental groups (whether or not they were politically powerful), then one might have expected the presence of broad-based groups to predict a change in rules. But interest-group type predicts nothing.

The fact that the economic significance of a rule is no predictor of change casts further doubt on the idea that the White House uses the review process as a cover to benefit politically powerful groups. To generalize a bit, such groups would seem most likely to oppose rules that would have an annual effect on the economy or adversely affect the economy or a sector of it. If so, then the economic significance of a rule should predict a higher probability of change in the rule during the review process. Because the White House is no more or less likely to change a rule that is economically significant, it does not appear that the White House treats those who object to economically significant rules more favorably than anyone else. Or to put the point more modestly, the finding that the economic significance of a rule does not predict a higher probability of a change certainly does not support the claim that White House review gives those unhappy with the costs a rule will impose upon them another forum in which to alter the rule.

Finally, the White House appears to concentrate on rules the subject matter of which the White House seems especially interested inin recent years, environmental rules in particular. This finding suggests first that White House review is substantive rather than perfunctory, in that the White House has developed expertise in environmental rulemaking. More to the immediate point, this finding also suggests that the White House does not opportunistically eviscerate whichever rules happen to generate opposition among politically important constituencies. Just as plausibly, the White House may concentrate on environmental rules because it is especially interested in environmental policy.

Of course, it could just be that powerful White House constituencies are most often bothered by environmental rules, in which case the White House's focus on environmental rules, and propensity to change them, might well confirm fears about the review process. That possibility is hard to disprove, but it seems rather implausible for the Clinton administration, which again according to most observers was friendly to environmental regulation. To know for sure, however, would require data about the types of changes the White House made to environmental rules during the review process and in particular their "direction"- that is, whether the White House typically strengthened, loosened, or changed in some other way the rules it re- 
viewed. While such data are not available, it is worth mentioning that for two of the most important (if not the two most important) environmental rules of the Clinton administration, the EPA's rules on ozone and particular matter-rules that were the subject of numerous OIRA meetings - the White House ultimately supported the EPA's controversial position to tighten ozone and particulate matter levels notwithstanding intense industry opposition and even though during the rulemaking review process some within the White House thought the rules' costs were too high." Whatever changes to environmental rules were made during the White House review process, then, the story that holds the White House used the review process to protect powerful interest groups from the EPA seems far too simple.

\section{B. Skepticism Toward Activist White House Oversight}

There are arguments to be made against the strong regulatory president, which find at least some support from the above findings. First, the data suggest that White House review is not simply a review for major rulemaking mistakes or inconsistencies. Rather, the White House has inserted itself into the rulemaking process in a thoroughgoing way. The evidence of this is considerable, including the size of the investment the White House has made in rulemaking review, both organizationally and as measured in terms of human resources. The White House's focus on fewer rules also evidences an activist role in rulemaking, especially given the increasing incidence of rule changes over recent years. The White House has also focused on environmental rules, with an even higher incidence of change. Thus, to the extent that defenders of White House oversight have argued that such oversight simply serves an inter-agency coordination role to avoid regulatory redundancy and inconsistency, White House review has become much more.

Second, critics of expanded White House oversight find some of their fears about uneven interest-group pressures and political favoritism realized by the finding that narrow interest groups outnumber all other types during the OIRA meeting process. Although almost half of the rules that were the subject of OIRA meetings led to broadbased pluralistic meetings, still more than half led to meetings attended only by narrow interest groups. While the type of interest groups represented at meetings do not predict a greater likelihood that a rule will be changed among the set of rules that are the subject of meetings, clearly rules that are the subject of meetings are more likely to be changed among the set of all rules under review. Thus,

77 See Croley, 28 Fla St U L Rev at 55-66 (cited in note 50) (detailing the controversy surrounding, and ultimate fate of, EPA's ozone and particulate matter rules). 
even if an OIRA meeting itself is not the cause of a change in a rule, a meeting reflects some underlying dynamic that leads to a change in a rule. If narrow interest groups are the only type mobilized against a rule when there is no OIRA meeting in the same proportion that they are when there is an OIRA meeting (54 percent of the time), that unobservable dynamic could mean that narrow interest groups are especially effective at prompting the White House to require changes in rules they oppose, although not formally through the mechanisms created by OIRA review.

More generally, if the existence of an OIRA meeting can be taken as an indicator of political controversy surrounding a rule, then the OIRA meetings data suggest that politically controversial rules are usually changed through the White House review process. That conclusion challenges the view of OIRA review as purely technocratic. If OIRA review is indeed primarily technocratic, then political controversy should not be the dominant engine prompting changes in submitted rules. Of course, controversial rules may also at times be particularly complex and therefore the most vulnerable to technocratic changes. But controversy itself should not be the primary explanation for changes in rules. Yet, taking the existence of an OIRA meeting as a proxy for political controversy, rules that are the subject of a meeting are far more likely to be changed during the review process, suggesting that controversy drives changes in rules required by the White House. Again, nothing follows from this strictly, but the observation is consistent with fears that White House review constitutes a forum for interest groups who object to aspects of a rule to enlist the White House to change it. At the very least, systematic White House alteration of controversial rules does nothing to calm such fears.

The positive correlation between agency presence at OIRA meetings and changes to rules the subject of those meetings might also provide support for worries that White House review inappropriately interferes with agency autonomy. That is, although the White House solicits agencies' views about rules under review and invites agencies to OIRA meetings, both as required by Executive Order 12866 and its implementing directives, it appears that agencies do not usually succeed in persuading White House reviewers that their rules would be best unchanged. There is a sense, after all, in which agencies and the White House occupy antagonistic positions, for the agency sends the White House a rule that the agency believes already responds to all implicated issues in the best possible way. Moreover, agencies submit rules acutely aware of the specific requirements of Executive Order 12866 and of the president's regulatory priorities generally. In that light, changes made during the review process ex- 
press the White House's view that an agency's rule as it stands is at least in part misguided. So while White House review is not autocratic in the sense that the White House does whatever it wants with a rule without regard to an agency's informed view, neither does White House review constitute cooperation among regulatory equals. Certainly White House review is activist in the sense that OIRA does not routinely defer to agency staff about why submitted rules already reflect the proper balance among implicated considerations.

Finally, although Executive Order 12866 sought to make White House review more transparent, in fact the process is merely translucent. OIRA does keep a log of meetings, but again only a small percentage of rules under review are ever the subject of meetings-an unusually important set, to be sure, but a small minority of rules nonetheless. Because there is no way to observe communications between other offices within the White House and OIRA for rules not the subject of an OIRA meeting, it is impossible to know how often and with what effect other offices within the White House make their views known to OIRA reviewers - facts that would be important to any final assessment of the political dimensions of the White House's influence on rulemaking. In addition, while Executive Order 12866 also required OIRA to maintain a phone log listing telephone communications between the OIRA Administrator and persons not employed by the executive branch of the government, ${ }^{78}$ in fact OIRA maintains no such log because it adopted the policy, immediately following Executive Order 12866, of no longer accepting phone calls about rules pending reviews. Outside persons were instead invited to request a face-to-face meeting. On the one hand, this means that interest groups can no longer make their objections to submitted rules known to OIRA staff except through a meeting, eliminating one possible channel for interest group influence over the White House, which critics of White House review should welcome. On the other hand, however, one could argue that the elimination of telephone communications provides an example of how a procedure designed to promote openness may have the opposite effect, as nothing stands in the way of interest groups contacting other White House offices to make their views known, and yet communications between other White House offices and OIRA are nowhere documented. And again, although Executive Order 12866 contains language instructing agencies to trace which changes to their rules were prompted by OIRA staff, in fact such records are difficult to obtain, in part no doubt because agencies revise their rules in anticipation of OIRA reactions before OIRA has formally responded to the written text of rules. 


\section{OIRA Rulemaking Review as Regulatory Good Government}

On balance, White House review of agency rulemaking probably is a welcome development in administrative governance. Ultimately, the debate over expanded White House oversight might be settled by the allocation of the burden of persuasion, for proving that White House oversight promotes good government is at least as difficult as proving that it does not. To the extent critics believe that White House oversight is unwelcome no matter how transparent and evenhandedunwelcome because, in principle, such oversight constitutes an unwarranted interference with agency autonomy and congressional willthere is probably little to be said to refute that conviction. To the extent that critics do not object to expanded White House oversight as a matter of principle, then data about how that oversight is exercised might challenge many of the common particular criticisms made of presidential involvement in rulemaking. Most of the data above go farther to assuage fears about presidential involvement in rulemaking than they do to accentuate those fears.

Not to overstate, additional improvements in transparency, for example, would further assuage fears about White House misuse of the rule review process. Although the Clinton order sought to promote greater transparency, some of its language exaggerates the extent to which changes to rules prompted by the White House are really identifiable to the public. ${ }^{79}$ Indeed, what is not observable may be much more threatening than what is observable. At the same time, the data that are available do not paint a disturbing picture. The White House seems to have the institutional capacity for conducting substantive review of rules. While the review process may provide opportunities for the White House to benefit favored political constituencies, the facts suggest more strongly that the White House uses rulemaking review more to put its own mark on regulation than it does to win or maintain political support from politically narrow yet powerful interests. The critics might be right, in the end, but if so they are right for reasons that do not appear on the surface of White House review.

And that surface is more revealing than one might think. Although a cynic would counter that White House brokered regulatory favoritism takes place through channels other than the OIRA review process-and indeed almost certainly some does-it is not clear exactly what those channels are or who has regular access to them. After all, rarely do interest groups, even the most powerful, have direct access to the president or vice president himself. Moreover, obvious presidential proximity to interest groups often creates considerable 
political liabilities for the White House. ${ }^{80}$ The same is true for other offices within the White House. Clearly, none is immune from interest group pressures, and offices like the National Economic Council and the Council on Environmental Quality are hardly inattentive to the political consequences of regulatory policy. But here too, it is the rare interest group that can directly and persistently push its regulatory preferences before other White House agencies.

Instead, the OIRA review process provides the greatest institutional forum for interest groups to pursue their regulatory goals before White House personnel. What is more, even where groups may successfully communicate their regulatory preferences to other parts of the White House, still those other arms must somehow influence the rule review process in order to deliver regulatory favors to important political constituencies. In other words, there simply are few opportunities for the White House to influence rulemaking completely independently of OIRA. So if the White House regularly delivers regulatory benefits to favored interest groups, that fact should somewhere be reflected in the OIRA review process data even if interestgroup communication with OIRA itself is not the mechanism by which interest groups obtain favorable regulatory treatment. To the extent the President would encourage favored groups to press their concerns to OIRA in order to provide the President with an opportunity to confer regulatory benefits on them, again presidential favoritism should show up in the data.

Thus, while it is true that examining available data concerning OIRA rulemaking review to some extent constitutes a case of looking where the light happens to be - but only to some extent, as none of the data presented above is publicized much less discussed - the point remains that it is unlikely a great deal of regulatory favoritism takes place in total darkness: Given the institutional position and importance of OIRA to the White House's oversight of agencies, it is hard to imagine that White House favoritism is pervasive completely outside of OIRA. Granted, behind-the-scenes rent-seeking is by its very nature hard to rule out, but for the same reason is hard to confirm as well. Undoubtedly, some amount of regulatory function by the White House takes place. Even so, it would be much too glib to dismiss the above findings that OIRA review appears to be evenhanded and

80 The current controversy surrounding the White House's reliance on advice and information from energy companies in conjunction with the Vice President's "National Energy Policy Development Group" is a recent case in point. See, for example, Senators Get Peek at Files on Enron, Chi Trib 9 (June 4, 2002); Michael Schmidt and Cathy Landry, Task Force Papers Create Talk of "Scandal", Inside Energy with Federal Lands 1 (Apr 1, 2002); Marcia Coyle, GAO. Cheney Lawsuit Has Legal Scholars Puzzled, Natl L J A8 (Feb 4, 2002). By all appearances at least, favored interests did get special access. But the White House paid a political price. 
technocratic as misleading or irrelevant to the question about the nature of White House review.

Moreover, if regulatory favoritism by the White House independent of the OIRA review process is common, that fact probably argues in favor of a greater, not a lesser, role for OIRA in rulemaking review. In other words, now OIRA review becomes an antidote to behind-the-scenes influence on agency rulemaking from other parts of the White House. The greater OIRA's relevance and influence, the more difficult it should be for other arms of the White House to affect the final form of agency rules. To the extent OIRA review is open and evenhanded, and to the extent OIRA evaluates rules against established criteria such as cost-benefit analysis and the president's own regulatory priorities, OIRA review probably impedes regulatory rentseeking elsewhere. After all, if the OIRA review process were eliminated altogether, as some critics of activist presidential oversight would seem to favor, some amount of White House influence pedaling would obviously persist. What is more, because presidential communications are largely constitutionally privileged, the White House itself is under limited obligation to reveal information either about the parties with whom it discusses regulatory policy or what the subject of any communications may be. In that sense, some of the directives of Executive Order 12866 providing for certain public disclosure of communications between OIRA and outside interests constitute voluntary transparency by the White House that should certainly be encouraged.

Finally, the question about the White House's proper role with respect to agency rulemaking should focus, as always, on the marginal effects of White House review. In other words, the real question asks whether White House review of agency rulemaking is desirable given all of the other features of the rulemaking process and all other influences on agency rulemaking. For example, the agency rulemaking process itself - as specified by the Administrative Procedure Act and that act's judicial interpretation-is largely though imperfectly open and accessible, and to the extent that procedure tends to yield socially desirable rules, White House review that threatens agency autonomy could be unwelcome. On the other hand, many see Congress as a corrupting influence on agency rulemaking that encourages if not forces agencies to protect important congressional constituencies. In that light, OIRA review could be a welcome correction for undesirable legislative influence on agency rulemaking that bolsters rather than jeopardizes agency autonomy. Several of the above findings-that OIRA evaluates agency rules with respect to established criteria, that OIRA apparently possesses the human and organizational resources to understand agency rules, that rulemaking agencies are consulted 
during the review process, that the presence of narrow interest groups at OIRA meetings does not affect the likelihood that a rule will be changed, that White House presence at OIRA meetings similarly does not affect the probability that a rule will be changed, and that in recent years the propensity of the White House to require changes in rules reflects as much as anything the administration's regulatory priorities (such as its focus on environmental regulation)-support such a conclusion.

\section{CONCLUSION}

As usual, the real world is inconveniently messy; none of its details proves all that much. Nonetheless, in the light of available facts about White House review of agency rulemaking during the past two decades, and during the Clinton era most especially, it seems that some of the common criticisms of expanded White House oversight are misguided. White House review in recent years appears to focus on particularly important agency rules of which there are a seemingly manageable number given the institutional resources the White House commits to rule review. Nor does the White House appear to cater to certain types of interests and not others. Different types of interest groups enjoy about equal opportunities for raising objections to pending rules before OIRA reviews. If OIRA meetings are well understood as indicators of larger controversy surrounding a given rule, the White House seems as likely to change a rule that is strongly opposed by some types of interest groups as it is to change a rule strongly opposed by different types of groups. Certainly rules that have especially important economic consequences seem not to be changed more often relative to other types of rules, which lends some modest support to the conclusion that the White House is not unduly solicitous of business-oriented interests.

On the other hand, not all types of interests groups take equal advantage of the opportunities to press their objections concerning pending rules before OIRA staff, although whether doing so yields any direct influence is questionable. Rather, narrowly interested groups do so much more often. In addition, the White House review process is not completely transparent, to say the least. Notwithstanding the changes brought about by Executive Order 12866 to open the White House review process to public scrutiny, the White House may make its wishes known to agencies in numerous ways that will have no public record, though the opportunities for doing so are at some point limited. Although Executive Order 12866 states that agencies are to document which changes in a rule were precipitated by the White House, in fact the rulemaking trail is seldom so clear. 
Moreover, the White House clearly has used rulemaking review to put its own mark on particular agency rules increasingly often over the course of the past two decades, and at an accelerated pace during the Clinton administration. Although it appears to have done so in a fairly if imperfectly translucent, open, and evenhanded way, such that many of the common criticisms of White House oversight seem off the mark, a question remains whether presidential participation in rulemaking-in decisions about the content of specific rules-is desirable no matter how open or evenhanded that participation may be. This question ultimately concerns the proper boundaries among the branches of government. Stubborn critics of presidential oversight might argue that no matter how apparently benign its form, the president simply has no business in rulemaking at the level of specific rules. The data presented above certainly do not settle that question. Nor would any. But insofar as the data show that White House review can be substantive and evenhanded, albeit not perfectly so, they do suggest that this normative question should be the remaining focal point of the debate over the strong president.

Having said that, the qualified defense of White House oversight provided here presupposes that the administration of President George W. Bush - and for that matter of future presidents - preserve and build upon the openness initiated by Executive Order 12866. In the absence of greater White House transparency, fears that the White House uses the rulemaking review process to deliver illicit regulatory favors to special interests will be impossible to dispel. Greater transparency is important not only in its own right, then, as a method to achieve greater regulatory objectivity, but because it allows for study of the oversight process to confirm, or disconfirm, that activist White House oversight is evenhanded.

Thus, the stakes are high. And, at least for the time being, the prognosis is good: In Executive Order 13258, President Bush preserved Executive Order 12866 by making clear that the current Bush White House would use the basic structure and methodology of Executive Order 12866, though with amendments relating to (and largely eliminating) the vice president's role. ${ }^{81}$ Similarly, the OMB's website continues to provide some significant information about the review process, going farther in that regard than was done during the Clinton administration. ${ }^{82}$ In short, the Bush administration has not fundamentally altered the oversight regime established by Executive Order 12866. At the same time, however, further steps to build upon

81 Exec Order 13258, reprinted in 67 Fed Reg 9385 (Feb 26, 2002).

82 See http://www.whitehouse.gov/omb/inforeg/oira_disclosure_memo-b.html (visited Mar 4, 2003). 
Executive Order 12866 to make the White House review process more transparent would be welcome.

Interestingly, John Graham, the current Administrator of OIRA, was, excepting judicial nominees, President Bush's most controversial appointment. The Senate vote on Administrator Graham's nomination was 61-37 in favor, ${ }^{83}$ with Senators Richard Durbin and Joseph Lieberman leading the opposition to Graham's confirmation. Since the vote, Senators Durbin and Lieberman have asked the GAO to undertake a study of the Bush White House's rulemaking review. Administrator Graham, who has been supportive of increased White House transparency since becoming the Administrator of OIRA, has solicited public and expert commentary on a new guidance document under which OIRA will conduct rulemaking review. ${ }^{85}$ The document, "Regulatory Analysis Guidance," covers both the procedural and the substantive aspects of OIRA review, including in particular a prescription for conducting cost-benefit analysis that would standardize agencies' cost-benefit analyses. In response to Administrator Graham's solicitation of commentary, the Administrative Law and Regulatory Practice Section of the American Bar Association has formed an ad hoc committee to review the draft guidance document and provide feedback that promotes transparency. Meanwhile, as noted above, ${ }^{86}$ the GAO has undertaken its study of rulemaking review during the Bush administration examining specifically what types of changes in submitted rules were made during the White House review process. The White House review process is thus currently the subject of much deserved attention.

Defenders of activist White House review would hope that the Bush administration secure, rather than dismantle, the translucency that currently characterizes OIRA rulemaking review. Of equal importance, the Bush White House should ensure that OIRA remains the locus of rulemaking review, and specifically that other offices within the White House do not ambush the rulemaking review process by requiring changes in rules under review that are outside of the OIRA review process. If the Bush White House were to assert control over rulemaking review through alternative, hidden channels, the most transparent OIRA review process imaginable might be worth little. Given the political controversy surrounding the Bush White House and its reliance on decisionmaking secrecy, preserving transparency and the centrality of OIRA review of agency rulemaking may

83 See Cindy Skrzycki, Overseer of the Rules for $O M B$, Wash Post E1 (July 31, 2001).

84 Id.

85 See Office of Management and Budget, Regulatory Matters, online at http://www.whitehouse.gov/omb/inforeg/regpol (visited Mar 2, 2003).

86 See note 70. 
not only promote good regulatory government, but make for smart politics as well. $^{87}$

\section{APPENDIX}

Examination of OIRA meetings and the rules the subject of those meetings used the following coding scheme:

Table A1: Variable Codes for OIRA Meetings

\begin{tabular}{|c|c|}
\hline Agency originating rule & Agency's name \\
\hline rule stage & $\begin{array}{l}1=\text { final } \\
0=\text { proposed }\end{array}$ \\
\hline rule significance type & $\begin{array}{l}1=\text { economically significant } \\
0=\text { otherwise significant }\end{array}$ \\
\hline written materials supplied at meeting & $\begin{array}{l}1=\text { yes } \\
0=\text { no }\end{array}$ \\
\hline agency attended meeting & $\begin{array}{l}1=\text { yes } \\
0=\text { no }\end{array}$ \\
\hline $\begin{array}{l}\text { interests represented: } \\
\text { narrow } \\
\text { broad-based } \\
\text { pluralistic } \\
\text { inter-governmental }\end{array}$ & $\begin{array}{l}\mathrm{NI}=1 ; \mathrm{BBI}=0 ; \mathrm{PL}=0 ; \mathrm{GOV}=0 \\
\mathrm{NI}=0 ; \mathrm{BBI}=1 ; \mathrm{PL}=0 ; \mathrm{GOV}=0 \\
\mathrm{NI}=0 ; \mathrm{BBI}=0 ; \mathrm{PL}=1 ; \mathrm{GOV}=0 \\
\mathrm{NI}=0 ; \mathrm{BBI}=0 ; \mathrm{PL}=0 ; \mathrm{GOV}=1\end{array}$ \\
\hline $\begin{array}{l}\text { White House (besides OIRA) at- } \\
\text { tended meeting }\end{array}$ & $\begin{array}{l}1=\text { yes } \\
0=\text { no }\end{array}$ \\
\hline $\begin{array}{l}\text { number of meetings: } \\
\text { one } \\
\text { two } \\
\text { more than two }\end{array}$ & $\begin{array}{l}M=1 ; M M=0 ; M M M=0 \\
M=0 ; M M=1 ; M M M=0 \\
M=0 ; M M=0 ; M M M=1\end{array}$ \\
\hline $\begin{array}{l}\text { rule was changed during review } \\
\text { process }\end{array}$ & $\begin{array}{l}1=\text { yes } \\
0=\text { no }\end{array}$ \\
\hline
\end{tabular}

87 See Skrzycki, Overseer of the Rules for $O M B$, Wash Post at E1 (cited in note 83) (noting that Administrator Graham has said he will work, at the behest of the OMB Director, "on openness and disclosure of meetings with OMB and other events leading up to a rulemaking," and that such a move is likely to be welcomed by congressional critics of the White House's recent secrecy surrounding energy and environmental policy). 


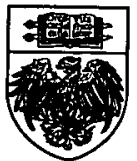

